medRxiv preprint doi: https://doi.org/10.1101/2022.02.24.22271384; this version posted February 25, 2022. The copyright holder for this preprint (which was not certified by peer review) is the author/funder, who has granted medRxiv a license to display the preprint in All rights reserved. No reuse allowed without permission.

\title{
Autonomic dysfunction is associated with the development of arterial stiffness: The Whitehall II cohort
}

Jonas Schaarup ${ }^{1,2}$, Martin S. Christensen ${ }^{3}$, Adam Hulman ${ }^{2}$, Christian Stevns Hansen ${ }^{4}$, Dorte Vistisen $^{4,5}$, Adam G. Tabák ${ }^{6,7,8}$, Daniel R. Witte ${ }^{1,2}$, Lasse Bjerg ${ }^{2,9}$

${ }^{1}$ Department of Public Health, Aarhus University

${ }^{2}$ Steno Diabetes Centre Aarhus, Aarhus University Hospital, Denmark

${ }^{3}$ Aarhus University, Aarhus, Denmark

${ }^{4}$ Steno Diabetes Centre Copenhagen, Copenhagen, Denmark

${ }^{5}$ Department of Public Health, University of Copenhagen, Copenhagen, Denmark

${ }^{6}$ Department of Epidemiology and Public Health, University College London, London, UK

${ }^{7}$ Department of Public Health, Semmelweis University Faculty of Medicine, Budapest, Hungary

${ }^{8}$ Department of Internal Medicine and Oncology, Semmelweis University Faculty of Medicine, Budapest, Hungary

${ }^{9}$ Department of Clinical Medicine, Aarhus University

Word count: 3792 (excluding figure legends)

Number of Figures and Tables: Tables: 1 (Supplementary tables: 1). Figures: 4 (Supplementary figures: 5)

Corresponding author:

Jonas Schaarup

Mail:jfrscha@ph.au.dk

Mobile: +45 29936899

Adresss: Steno Diabetes Center Aarhus,

Hedeager 3, 2nd floor, 8200 Aarhus N

Denmark 
medRxiv preprint doi: https://doi.org/10.1101/2022.02.24.22271384; this version posted February 25, 2022. The copyright holder for this preprint (which was not certified by peer review) is the author/funder, who has granted medRxiv a license to display the preprint in All rights reserved. No reuse allowed without permission.

\section{Abbreviations}

ECG: Electrocardiogram

CAN: Cardiovascular autonomic neuropathy

CVD: Cardiovascular disease

HF power: High-frequency power

HRV: Heart rate variability

LF power: Low-frequency power

PWV: pulse wave velocity

SDNN: The standard deviation of normal-to-normal R-R intervals

rHR: Resting heart rate

RMSSD: The root mean square of the sum of the squares of differences between consecutive normal-to-normal R-R intervals 
medRxiv preprint doi: https://doi.org/10.1101/2022.02.24.22271384; this version posted February 25, 2022. The copyright holder for this preprint (which was not certified by peer review) is the author/funder, who has granted medRxiv a license to display the preprint in

All rights reserved. No reuse allowed without permission.

\section{Abstract}

Background and aim: To examine the association between baseline level and change of autonomic nervous function with subsequent development of arterial stiffness.

Methods: Autonomic nervous function was assessed of 4,901 participants of the Whitehall II occupational cohort by heart rate variability (HRV) indices and resting heart rate (rHR) three times between 1997-2009, while arterial stiffness was assessed by carotid-femoral pulse wave velocity (PWV) measured twice between 2007-2013. First, individual HRV/rHR levels and annual changes were estimated. Then, we modelled the development of PWV by HRV/rHR using linear mixed effect models. First, we adjusted for sex and ethnicity (model 1), and then for socioeconomic and lifestyle factors, various clinical measurements, and medications (model 2).

Results: A decrease in HRV and unchanged rHR was associated with subsequent higher levels of PWV, but the effect of a change in HRV was less pronounced at higher ages. A typical individual aged 65 years with a SDNN level of $30 \mathrm{~ms}$ and a 2\% annual decrease in SDNN had 1.32 (0.95; 1.69) higher PWV compared to one with the same age and SDNN level but with a $1 \%$ annual decrease in SDNN. Further adjustment had no major effect on the results.

Conclusion: People who experience a steeper decline of autonomic nervous function have higher levels of arterial stiffness. However, the association was weaker at higher ages.

Keywords: Autonomic nervous function, Heart Rate Variability, Arterial Stiffness, Longitudinal study, Whitehall II study, Pulse Wave Velocity. 
medRxiv preprint doi: https://doi.org/10.1101/2022.02.24.22271384; this version posted February 25, 2022. The copyright holder for this preprint (which was not certified by peer review) is the author/funder, who has granted medRxiv a license to display the preprint in

All rights reserved. No reuse allowed without permission.

\section{Introduction}

According to the World Health Organization, cardiovascular disease (CVD) is the leading cause of morbidity and mortality worldwide (1). CVD mortality markedly declined in high-income countries through the adoption of preventive measures and more targeted and effective risk factor management and treatment (2). Intermediate end-points on the causal pathway towards CVD are of high interest as they may identify individuals with elevated CVD risk at an earlier time-point than the conventional CVD risk stratification tools (3) and may open the opportunity for early management and treatment in those who have highest CVD risk.

Arterial stiffness is increasingly acknowledged as a subclinical indicator of cumulative CVD risk and also as an intermediate end-point for CVD (4-7). The gold standard method for its evaluation is the assessment of aortic pulse wave velocity (PWV). PWV is determined non-invasively by measuring the speed at which the arterial pressure waves move through the descending aorta (8), a feature directly dependent on the stiffness of the aorta. Arterial stiffness is primarily determined by the composition of the structural components of the arterial wall (9). In youth, arteries are compliant and elastic (8). With aging, elastin fibres are gradually replaced with stiffer collagen fibres, leading to progressively less elastic arterial wall (10). This process can be accelerated by modifiable risk factors such as smoking, hypertension, dysglycaemia, and hyperlipidaemia (8). As such, arterial stiffness may act as a proxy of the summed exposure to cardiometabolic risk factors (11). However, arterial stiffness is also modulated dynamically under the control of direct local endothelial signals and studies have shown an association between sympathetic tone and increased arterial stiffness (12).

The autonomic nervous system plays an important role in adaptive changes of cardiac and vascular responsiveness to internal and external requirements (13). Abnormal function of the autonomic nervous system as seen in cardiac autonomic neuropathy (CAN) may lead to maladaptive vascular dynamics and an abnormally invariant heart rate. Heart rate variability (HRV) is a validated measure for assessing CAN (14). HRV is defined as the beat-to-beat variability heart rate that provides an estimate of the balance between the sympathetic and parasympathetic tone. HRV can be measured based on electrocardiographic traces (ECG)(13). 
medRxiv preprint doi: https://doi.org/10.1101/2022.02.24.22271384; this version posted February 25,2022 . The copyright holder for this preprint (which was not certified by peer review) is the author/funder, who has granted medRxiv a license to display the preprint in

All rights reserved. No reuse allowed without permission.

An association between autonomic dysfunction and increased arterial stiffness is well established in both type 1 diabetes and type 2 diabetes (15-18). Furthermore, studies have shown that autonomic imbalance is already present in individuals with prediabetes (19) and CAN is associated with lower insulin sensitivity in a individuals without diabetes (20). CAN is also a predictor of incident diabetes and vascular diseases (21). This suggests both that autonomic dysfunction not only exists in people with established diabetes, it may also be associated with arterial stiffness independently of hyperglycaemia.

Our hypothesis is that individuals with preserved autonomic nervous function have lower levels of arterial stiffness and slower progression of arterial stiffening. In this etiological longitudinal analysis, we will examine to which degree individual levels and change in autonomic nervous function are associated with the progression of arterial stiffness in a general population.

\section{Materials and methods}

\subsection{Study population}

The Whitehall II study is an occupational cohort that originally included 10308 (3413 women and 6895 men) British civil servants in the age range of 35-55 years at recruitment in 1985. The cohort was invited for a clinical examination approximately every 5 years and additionally received a questionnaire every 2-3 years. HRV and resting heart rate (rHR) were first measured in phase 5 (1997-1999) and further obtained in phases 7 (2002-2004) and 9 (22). PWV was first measured in phase 9 (2008-2009), considered as baseline in the current study, and then in phase 11 (2012-2013). The inclusion criteria in this investigation were having at least one measurement of HRV, rHR and PWV and complete information on covariates.

The Whitehall II study was reviewed and approved by the UK NHS Health Research Authority London-Harrow Ethics Committee and written informed consent was obtained from each participant at each examination phase. The study was conducted according to the principles of the Helsinki Declaration. 
medRxiv preprint doi: https://doi.org/10.1101/2022.02.24.22271384; this version posted February 25,2022 . The copyright holder for this preprint (which was not certified by peer review) is the author/funder, who has granted medRxiv a license to display the preprint in

All rights reserved. No reuse allowed without permission.

\subsection{Exposure}

Resting heart rate (rHR) was measured in 5-minute resting 12-lead ECG recordings obtained after 5 minutes of rest in the supine position. Then, the normal-to-normal (NN) sinus rhythm was determined from the recordings with an automated algorithm to identify R-R intervals without the presence of arrhythmias, ectopic beats and/or branch-blocks. These measurements were used to calculate HRV indices in the time and frequency domain (23). We included the HRV exposures of time domain: standard deviation of the $\mathrm{NN}$ interval (SDNN) and root mean square of successive differences (RMSSD), and frequency domain by using a Blackman-Tukey algorithm: low frequency (in the $0.04-0.15 \mathrm{~Hz}$ frequency band) (LF) and high frequency (in the $0.15-0.4 \mathrm{~Hz}$ frequency band) (HF). To account for cardiac automatism from concurrent heart rate, we included inter-beat interval corrected HRV (cHRV), an approach described in Van Roon et al. (24-26) (supplemental material). rHR was included as a control exposure to supplement the analysis.

\subsection{Outcome}

Aortic stiffness was characterised by aortic pulse wave velocity (PWV), which is calculated from the time between the ECG systole and the arrival of the pressure wave at the femoral and carotid measurement sites and the distance between these two measurement sites. Applanation tonometry is a validated method for assessing carotid-femoral PWV (SphygmoCor, Atcor Medical, Australia). PWV measurements were performed in a supine position after 10 minutes of rest. The aortic path length was determined with a tape measure by subtracting the carotid-sternal notch distance from the femoral-sternal notch distance. PWV was measured twice for each participant and the average was calculated (27). If the recordings differed by more than $0.5 \mathrm{~m} / \mathrm{s}$, a third measurement was performed and the average of the two closest measurements was used for the analysis.

\subsection{Covariates}

Self-administered questionnaires included information on categorical covariates such as smoking (never, former, current), socioeconomic status (administrative, professional/executive, clerical support), medication use (antihypertensive, cardiovascular, and antidiabetic medication), incidence of hypertension and other CVD), and continuous variables such as physical activity (hours of moderate to vigorous exercise) and alcohol use (units last week). Information on body mass index (BMI), waist-hip ratio, high-density lipoprotein (HDL), low-density lipoprotein (LDL), total 
medRxiv preprint doi: https://doi.org/10.1101/2022.02.24.22271384; this version posted February 25,2022 . The copyright holder for this preprint (which was not certified by peer review) is the author/funder, who has granted medRxiv a license to display the preprint in All rights reserved. No reuse allowed without permission.

cholesterol, triglycerides, haemoglobin A1c (HbA1c), oral glucose tolerance test (OGTT), and fasting plasma glucose (FPG) were collected as continuous covariates at clinical examination.

Diagnosis of diabetes was based on a combination of the 1999 and 2006 WHO guidelines $(28,29)$ : FPG $\geq 7.0 \mathrm{mmol} / 1,2-\mathrm{h}$ postload plasma glucose $(2-\mathrm{h}$ PG) $\geq 11.1 \mathrm{mmol} / 1$ during an OGTT, HbAlc $\geq 6.5 \%$, or self-reported diagnosis. The OGTT was not part of the study protocol at phase 11 . Therefore, diagnosis at phase 11 is only based on FPG, HbA1c and self-report.

\subsection{Statistical analysis}

Descriptive analyses were performed by each study phase to characterize the distribution of continuous variables (median, $25^{\text {th }} \& 75^{\text {th }}$ percentile) and frequencies (numbers, percentage) for categorical variables.

To examine individual-specific levels and changes in HRV/ rHR and their effect on PWV development, we used a 2-step analysis approach. Step 1: HRV and rHR trajectories were analysed separately using linear mixed-effect models to account for the repeated measurement structure in the data (30). The intercept (value for a given age) and slope (age) were included both as fixed and random effects. Person-specific levels and changes in HRV and rHR were estimated by combining these fixed and random effects. Levels were estimated for each participant's age at phase 9 (study baseline). HRV values were log-transformed prior to analysis to obtain normally distributed model residuals. The person-specific HRV levels were transformed back to the original scale, while annual changes were expressed as a percentage. The estimated person-specific HRV/rHR levels at the phase 9 baseline and changes prior to baseline were then used as the exposures in the second step. Step 2: A linear mixed effect model was used to analyse the association between person-specific HRV/rHR estimates (both level and change) and PWV trajectories at phase 9 and 11. To assess PWV age-trajectories, we included age in the model (as both fixed and random effect) and its interaction with the exposures (HRV or rHR level and change estimated in step 1). Two models were fitted with different degrees of adjustment: model 1 was adjusted for ethnicity and sex; model 2 was further adjusted for socioeconomic status (SES), BMI, smoking status, alcohol use, physical activity, levels of total cholesterol, triglycerides, HbAlc, systolic blood pressure, anti-hypertensive medication and glucose lowering medication. We present the development of PWV as 5-year 
medRxiv preprint doi: https://doi.org/10.1101/2022.02.24.22271384; this version posted February 25, 2022. The copyright holder for this preprint (which was not certified by peer review) is the author/funder, who has granted medRxiv a license to display the preprint in All rights reserved. No reuse allowed without permission.

trajectories based on typical combinations of age and corresponding HRV/ rHR levels at phase 9 and typical levels of annual change (Supplementary Table 1S and Fig. 1S).

As earlier studies suggest that HRV should be adjusted for concurrent $\mathrm{rHR}(31,32)$, we conducted similar analysis using rHR corrected HRV indices: SDNN (cSDNN), RMSSD (cRMSSD), HF (cHF), LF (cLF). A subgroup analysis was performed including only those without diabetes. Hereby, the participants with diabetes (before phase 9 or 11) were excluded (this analysis was not adjusted for glucose lowering medication in model 2).

Complete case analyses were conducted. Analyses were performed using R version 3.6.2, using the nlme and Epi packages.

\section{Results}

From the entire cohort, 6412 (62\%) participants had at least one measurement of HRV, 5069 (49\%) participants among them also had at least one measurement of PWV, where 4901 (48\%) had full information on covariates (Figure 1). Regarding HRV, 1071 (22\%) had one measurement, 2312 (47\%) had two, and 1518 (31\%) had three. In total, 1494 (30\%) had one PWV assessment and 3407 $(70 \%)$ had two. In phase 5 , the median $\left(25^{\text {th }} ; 75^{\text {th }}\right.$ percentile $)$ age was 54.0 years $(50.2 ; 59.6), 26 \%$ were women, and the median SDNN was $35.4 \mathrm{~ms}(26.6 ; 46.2)$. In phase 9, considered the baseline for our analyses, median PWV was $8.04 \mathrm{~m} / \mathrm{s}(7.02 ; 9.44)$. The median interval for collection of data was 10.4 years $(10.2 ; 10.7)$ for the exposures (phase 5 to 9$)$ and 4.1 years $(4.0 ; 4.2)$ for the outcomes (phase 9 to 11). Further characteristics of the participants are summarised by phase in Table 1. The subpopulation included 4207 participants, as 694 participants were diagnosed with diabetes before phase 9 .

\subsection{HRV / rHR levels and annual change}

Model-based individual-specific HRV indices and rHR levels and annual change by age are summarised in Table 1S in the supplementary material. HRV decreased with age, and the HRV levels were lower in older age groups. E.g the annual median $\left(25^{\text {th }}\right.$ percentile; $75^{\text {th }}$ percentile $)$ decrease for SDNN was $-1.5 \%(-1.9 ;-1.1)$ irrespective of age and the median SDNN level for individuals aged below 65 years was $32.9 \mathrm{~ms}$ (28.5; 37.5), while for individuals aged above 70 
medRxiv preprint doi: https://doi.org/10.1101/2022.02.24.22271384; this version posted February 25, 2022. The copyright holder for this preprint (which was not certified by peer review) is the author/funder, who has granted medRxiv a license to display the preprint in All rights reserved. No reuse allowed without permission.

years it was $27.4 \mathrm{~ms}(22.4 ; 33.6)$ (Table 1S). Furthermore, there was a strong correlation between estimated levels at phase 9 and annual change for both exposures, rHR and HRV (Figure 1S).

\subsection{Association between level and change in HRV/ rHR estimates and the development of PWV}

5-year PWV trajectories were estimated for a combination of typical HRV levels and changes based on the analysis in step 1 (Figures $2 \& 3$ ). We chose to show our results at the corresponding median HRV levels at age interval 60-65, 65-70 and 70-75 respectively and modelled two scenarios with regards to annual change (HRV with either a smaller or steeper decrease).

Those with a steeper decrease of HRV indices (SDNN, LF, RMSSD and HF) had a higher level of PWV than those with a less steep decrease (Figure 2 \& 3). However, the effect of change in HRV indices was less pronounced at higher ages. E.g., based on model 1, the PWV difference between individuals with $-2 \%$ and $-1 \%$ annual change in SDNN was $1.78 \mathrm{~m} / \mathrm{s}(95 \mathrm{CI}: 1.28 ; 2.28)$ at age 60 and $0.88 \mathrm{~m} / \mathrm{s}(95 \mathrm{CI}: 0.55 ; 1.21)$ at age 70 (supplemental Fig. S3A and Table S2). Those with a steeper decrease in HRV had a slower annual increase in PWV than for those with a less pronounced decreasing HRV trajectory. Further adjustment (Model 2) had minor impact on these results (Figure $2 \& 3$ ). After the HRV indices were adjusted for their concurrent heart rate, the difference in PWV level was diminished (Figure 2 \& 3).

In the sub-population without diabetes, the results were persistent in model 1, and after the further adjustments of model 2 (supplemental Fig. S5c and Fig. S5d). As this analysis, did not differ from the main population, it was not further investigated (Supplementary fig 5S.).

5-year PWV trajectories were estimated for a combination of typical rHR levels and changes based on the analysis in step 1 (Figure 3). We chose to show our results at rHR levels of 65, 67 and 70 bpm at ages 60, 65 and 70, respectively and modelled two scenarios with regards to change (-0.2 bpm/year and 0.0 bpm/year). PWV levels and changes are summarized in Table 2.

Those with no HR change had a higher level of PWV than those with $-0.2 \mathrm{bpm} / \mathrm{year} \mathrm{rHR}$ change regardless of age (Figure 3 \& Table 2) The difference was $1.34 \mathrm{~m} / \mathrm{s}$ (95CI: 0.56; 2.13) at age 60 and $0.77 \mathrm{~m} / \mathrm{s}(95 \mathrm{CI}: 0.16 ; 1.37)$ at age 70 (supplemental Fig. S4 and Table 2S). rHR had a smaller 
medRxiv preprint doi: https://doi.org/10.1101/2022.02.24.22271384; this version posted February 25,2022 . The copyright holder for this preprint (which was not certified by peer review) is the author/funder, who has granted medRxiv a license to display the preprint in All rights reserved. No reuse allowed without permission.

effect on PWV slope than on level. Those with an increasing $\mathrm{rHR}(0.0 \mathrm{bpm} / \mathrm{year})$ had a $0.12 \mathrm{~m} / \mathrm{s}$ (95CI: 0.08; 0.16) annual increase in PWV, which was 0.06 (95CI: -0.02; 0.13) slower than for those with a decreasing rHR trajectory (-0.2 bpm/year). Further adjustment (Model 2) did not have a major effect on the results.

\section{Discussion}

In this study of 4,901 individuals, we showed how autonomic nervous function decreased with age, while resting heart rate tended to remains constant. Individuals with a steeper decline in autonomic nervous function or with an unchanged rHR had subsequent higher levels of arterial stiffness. However, this association was less pronounced at higher ages.

Several studies have found lower autonomic nervous function assessed by HRV indices to be associated with arterial stiffness in individuals with either type 1 or type 2 diabetes, suggesting that autonomic nervous function may play a mediating role in the association between diabetes and the development of arterial stiffness $(15,16,18,33,34)$. Our finding of an association between autonomic nervous function and arterial stiffness in a general population and in a subgroup without diabetes, extends these findings and suggests a relation between autonomic nervous function and arterial stiffness also in the absence of diabetes.

In contrast to this study, previous studies have mainly been cross-sectional and did not examine the longitudinal association between level and change of autonomic nervous function with development of arterial stiffness $(15,16,18,33,34)$. Two possible mechanisms might explain how the steeper decrease in autonomic nervous function is related to higher level of arterial stiffness. First, a decrease in autonomic nervous function may influence the elasticity of the arterial wall by increasing the vascular tone of large arteries. In rats, adequate autonomic nervous function is important in the maintenance of the elasticity in the aorta, suggesting that increased sympathetic activity can cause damage to elastin fibres, resulting in reduced elasticity (17, 34-36). However, results observed in animal models cannot be translated directly to human population studies. Second, heart rate is under strong autonomic control, and autonomic dysfunction not only leads to lower heart rate variability, but also to a higher resting heart rate. A higher resting heart rate in turn increases arterial stiffness, likely through alterations in blood flow dynamics leading to higher shear stress (37). A previous study in a general population has shown that increased resting heart rate is 
medRxiv preprint doi: https://doi.org/10.1101/2022.02.24.22271384; this version posted February 25, 2022. The copyright holder for this preprint (which was not certified by peer review) is the author/funder, who has granted medRxiv a license to display the preprint in All rights reserved. No reuse allowed without permission.

associated with arterial stiffness (38), which is also supported by our findings of an association between rHR levels and its change, and the development of arterial stiffness. We are aware that there is an inverse relationship between rHR and HRV, indicating that HRV are not only affected by autonomic nervous function, but also cardiac automatism. We have attempted to accommodate the influence of concurrent rHR on HRV. After the adjustment of HRV indices that is influenced by both sympathetic and parasympathetic activity (SDNN and LF) for concurrent rHR the association between autonomic dysfunction and development of arterial stiffness was substantially diminished, whereas HRV indices influenced by parasympathetic activity (RMSSD and HF) was less affected. Still, there has not been developed a standardized method of adjusting HRV for cardiac automatism, (25) hence we present both rHR adjusted and non-adjusted HRV models.

We assessed potential covariates through literature to minimize the impact of confounding on the association between HRV and PWV considering sex, ethnicity, socioeconomic and lifestyle factors, various clinical and lab measurements as well as medications. Our initial models were adjusted for sex and ethnicity. After further adjustment for SES, BMI, smoking status, alcohol use, physical activity, total cholesterol, triglycerides, HbAlc, systolic blood pressure, antihypertensive and glucose lowering medication, the association between change in autonomic nervous function and the development of arterial stiffness was attenuated. This suggests that part of the association can be explained by confounding by these covariates, that contribute both to the development of autonomic dysfunction and to arterial stiffness.

In principle, our models yield separate estimates for the effects of HRV level and change. However, we believe that the results can only be understood by considering observed combinations of the two determinants. E.g. if we examined the independent association between HRV levels and PWV (at a fixed rate of annual HRV change), it would seem that lower HRV levels were associated with lower PWV. We believe that this is probably due to the very strong positive correlation between HRV levels and their annual change in the study population, meaning that the strongest annual decline in HRV occurs in those with lowest HRV levels. Analysis of the effect of levels at a fixed rate of change would thus attempt to isolate the effect of the variation in levels not explained by the strong effect of annual change. To avoid these issues, our results are presented for (modelled) typical individuals within the observed ranges and combinations of HRV level and annual change. 
medRxiv preprint doi: https://doi.org/10.1101/2022.02.24.22271384; this version posted February 25, 2022. The copyright holder for this preprint (which was not certified by peer review) is the author/funder, who has granted medRxiv a license to display the preprint in

All rights reserved. No reuse allowed without permission.

As the association between autonomic dysfunction and arterial stiffness has previously been described in patients with diabetes, it would be particularly relevant to investigate if an individual's glycaemic state has a modifying effect on the association between changes in autonomic nervous function and arterial stiffness. Although the current study is a longitudinal study and the outcome trajectories were assessed after the exposure trajectories, we cannot draw definitive causal conclusions, as other unmeasured or unknown common causes could still confound our findings. We can also not fully discount the theoretical possibility that arterial stiffness may have caused changes in autonomic nervous dysfunction (reverse causation). However, no obvious biologically plausible mechanisms point in this direction.

\subsection{Strengths and limitations}

Our study contains a relatively large study population with repeated measurement of exposures, outcomes and covariates. This is a methodological strength in our study due to the possibility to examine how the individual level and change in autonomic nervous function contributes to the development of arterial stiffness. The benefit of using linear mixed effect models is that this approach does not require having the same number of measurements or same time of recordings for each participant and thus makes optimal use of all available data (39). However, in the current study, the two exposures (HRV level and change) are correlated.

Of the 10,308 participants, 3,896 were excluded due to missing data on HRV, either because of death, non-response or withdrawal. Of the 6,412 with HRV measured, 1,511 did not have any PWV assessment or complete information on covariates. However, this group did not differ from the study population with regards to general characteristics. Participants had to survive until phase 9 to be included. This may introduce healthy survivor bias which may have led to some underestimation of the association between HRV and PWV. Presumably, those who died before phase 9 had a steeper decrease in autonomic nervous function. Also, they might have higher level and increase in PWV.

The HRV index SDNN and LF mainly reflects the effect of both the parasympathetic and sympathetic function, whereas RMSSD and HF power mainly reflect parasympathetic activity (23). Some of these measures may best reflect longer-term HR variability patterns and hence require ECG traces covering a full or even multiple days. In addition, none of the available HRV indices 
medRxiv preprint doi: https://doi.org/10.1101/2022.02.24.22271384; this version posted February 25, 2022. The copyright holder for this preprint (which was not certified by peer review) is the author/funder, who has granted medRxiv a license to display the preprint in

All rights reserved. No reuse allowed without permission.

reflect sympathetic activity independently. The short-term reproducibility of aortic PWV was documented in another study using the Whitehall II dataset with PWV as outcome. The authors invited 125 participants after phase 9 to undergo the entire clinical examination a second time within 60 days of the original examination. The examinations showed good reproducibility i.e. the median $\left(25^{\text {th }}\right.$ percentile, $75^{\text {th }}$ percentile $)$ intra-individual difference in PWV was $0.08 \mathrm{~m} / \mathrm{s}(-0.68$; $0.93)(27)$.

The Whitehall II study is a UK-based occupational cohort, reflecting the constitution of the civil service in 1985. Women and non-white ethnic groups are underrepresented, placing some limitations on the generalizability of our results to wider populations.

\section{Conclusion}

In conclusion, our study suggests that among middle-aged and older adults decreasing autonomic nervous function is associated with higher levels of arterial stiffness. Our findings extend our understanding of the mechanisms involved in the development of CVD risk, by quantifying the association between the age-related decrease in autonomic nervous function and arterial stiffness.

\section{Acknowledgements}

We thank all participating women and men in the Whitehall II Study, as well as all Whitehall II research scientists, study and data managers and clinical and administrative staff who make the study possible. JS acknowledges support by Steno Diabetes Center Aarhus, which is partially funded by an unrestricted donation from the Novo Nordisk Foundation.

\section{Authors' contributions}

Study concept and design: JS, DRW, AH, MSC, LB, DV, CSH. Contributed the data: DRW, AGT. Planning the statistical analysis: JS, DRW, AH, LB, MSC, DV. Conducted the statistical analysis: JS. All authors contributed to, critically revised, and approved the final version of the manuscript. JS is the guarantor of this work and holds the final responsibility for the decision to submit for publication. 
medRxiv preprint doi: https://doi.org/10.1101/2022.02.24.22271384; this version posted February 25, 2022. The copyright holder for this preprint (which was not certified by peer review) is the author/funder, who has granted medRxiv a license to display the preprint in perpetuity.

All rights reserved. No reuse allowed without permission.

\section{Funding}

The UK Medical Research Council (K013351, R024227), British Heart Foundation and the US National Institutes of Health (R01HL36310, R01AG013196) have supported collection of data in the Whitehall II study.

\section{Ethics}

The study was approval The UK NHS Health Research Authority London-Harrow ethics committee approved the study which was conducted in accordance with the Helsinki Declaration with written informed consent from all participants.

\section{Conflicts of interests}

All the authors declare that there is no duality of interest associated with their contribution to this manuscript.

\section{Availability of data and materials}

Whitehall II data, protocols, and other metadata are available to bona fide researchers for research purposes. Please refer to the Whitehall II data sharing policy at https://www.ucl.ac.uk/epidemiology-health-care/research/epidemiology-and-publichealth/research/whitehall-ii/data-sharing 
medRxiv preprint doi: https://doi.org/10.1101/2022.02.24.22271384; this version posted February 25, 2022. The copyright holder for this preprint (which was not certified by peer review) is the author/funder, who has granted medRxiv a license to display the preprint in perpetuity.

All rights reserved. No reuse allowed without permission.

\section{References}

1. Mendis S, Puska P, Norrving B, World Health Organization. Global atlas on cardiovascular disease prevention and control: Geneva: World Health Organization; 2011.

2. Ford ES. Trends in predicted 10-year risk of coronary heart disease and cardiovascular disease among US adults from 1999 to 2010. Journal of the American College of Cardiology. 2013;61(22):2249-52.

3. Levi-Marpillat N, Desamericq G, Akakpo S, Affes-Ayadi H, Tropeano A-I, Millasseau S, et al. Crucial importance of using a sliding calliper to measure distance for carotid-femoral pulse wave velocity assessment. Journal of hypertension. 2013;31(5):940-5.

4. Vlachopoulos C, Aznaouridis K, Stefanadis C. Prediction of cardiovascular events and allcause mortality with arterial stiffness: a systematic review and meta-analysis. J Am Coll Cardiol. 2010;55(13):1318-27.

5. Laurent S, Cockcroft J, Van Bortel L, Boutouyrie P, Giannattasio C, Hayoz D, et al. Expert consensus document on arterial stiffness: methodological issues and clinical applications. European heart journal. 2006;27(21):2588-605.

6. Mitchell GF, Hwang S-J, Vasan RS, Larson MG, Pencina MJ, Hamburg NM, et al. Arterial stiffness and cardiovascular events: the Framingham Heart Study. Circulation. 2010;121(4):505.

7. Mansour AS, Yannoutsos A, Majahalme N, Agnoletti D, Safar ME, Ouerdane S, et al. Aortic stiffness and cardiovascular risk in type 2 diabetes. J Hypertens. 2013;31(8):1584-92.

8. Sethi S, Rivera O, Oliveros R, Chilton R. Aortic stiffness: pathophysiology, clinical implications, and approach to treatment. Integrated blood pressure control. 2014;7:29.

9. Cheung Y-F. Arterial stiffness in the young: assessment, determinants, and implications. Korean circulation journal. 2010;40(4):153-62.

10. Shirwany NA, Zou MH. Arterial stiffness: a brief review. Acta Pharmacol Sin. 2010;31(10):1267-76.

11. Nilsson PM, Boutouyrie P, Laurent S. Vascular aging: a tale of EVA and ADAM in cardiovascular risk assessment and prevention. Hypertension (Dallas, Tex : 1979). 2009;54(1):3-10. 12. Bruno RM, Ghiadoni L, Seravalle G, Dell'Oro R, Taddei S, Grassi G. Sympathetic regulation of vascular function in health and disease. Front Physiol. 2012;3:284.

13. Rajendra Acharya U, Paul Joseph K, Kannathal N, Lim CM, Suri JS. Heart rate variability: a review. Med Biol Eng Comput. 2006;44(12):1031-51.

14. Camm AJ, Malik M, Bigger JT, Breithardt G, Cerutti S, Cohen R, et al. Heart rate variability: standards of measurement, physiological interpretation and clinical use. Task Force of the European Society of Cardiology and the North American Society of Pacing and Electrophysiology. 1996.

15. Jensen-Urstad K, Reichard P, Jensen-Urstad M. Decreased heart rate variability in patients with type 1 diabetes mellitus is related to arterial wall stiffness. Journal of internal medicine. 1999;245(1):57-61.

16. Chorepsima S, Eleftheriadou I, Tentolouris A, Moyssakis I, Protogerou A, Kokkinos A, et al. Pulse wave velocity and cardiac autonomic function in type 2 diabetes mellitus. BMC Endocr Disord. 2017;17(1):27.

17. Chandra P, Sands RL, Gillespie BW, Levin NW, Kotanko P, Kiser M, et al. Relationship between heart rate variability and pulse wave velocity and their association with patient outcomes in chronic kidney disease. Clinical nephrology. 2014;81(1):9. 
medRxiv preprint doi: https://doi.org/10.1101/2022.02.24.22271384; this version posted February 25, 2022. The copyright holder for this preprint (which was not certified by peer review) is the author/funder, who has granted medRxiv a license to display the preprint in perpetuity.

All rights reserved. No reuse allowed without permission.

18. Tentolouris N, Liatis S, Moyssakis I, Tsapogas P, Psallas M, Diakoumopoulou E, et al. Aortic distensibility is reduced in subjects with type 2 diabetes and cardiac autonomic neuropathy. European journal of clinical investigation. 2003;33(12):1075-83.

19. Papanas N, Vinik AI, Ziegler D. Neuropathy in prediabetes: does the clock start ticking early? Nature Reviews Endocrinology. 2011;7(11):682.

20. Saito I, Hitsumoto S, Maruyama K, Nishida W, Eguchi E, Kato T, et al. Heart rate variability, insulin resistance, and insulin sensitivity in Japanese adults: The Toon Health Study. Journal of epidemiology. 2015:JE20140254.

21. Wulsin LR, Horn PS, Perry JL, Massaro JM, D'Agostino RB. Autonomic imbalance as a predictor of metabolic risks, cardiovascular disease, diabetes, and mortality. The Journal of Clinical Endocrinology \& Metabolism. 2015;100(6):2443-8.

22. Marmot M, Brunner E. Cohort profile: the Whitehall II study. International journal of epidemiology. 2005;34(2):251-6.

23. Hansen CS, Faerch K, Jorgensen ME, Malik M, Witte DR, Brunner EJ, et al. Heart Rate, Autonomic Function, and Future Changes in Glucose Metabolism in Individuals Without Diabetes: The Whitehall II Cohort Study. Diabetes Care. 2019;42(5):867-74.

24. van Roon AM, Snieder H, Lefrandt JD, de Geus EJC, Riese H. Parsimonious Correction of Heart Rate Variability for Its Dependency on Heart Rate. Hypertension (Dallas, Tex : 1979). 2016;68(5):e63-e5.

25. de Geus EJC, Gianaros PJ, Brindle RC, Jennings JR, Berntson GG. Should heart rate variability be "corrected" for heart rate? Biological, quantitative, and interpretive considerations. Psychophysiology. 2019;56(2):e13287.

26. 2. Classification and Diagnosis of Diabetes: \&lt;em\&gt;Standards of Medical Care in Diabetes-2019\&1t;/em\&gt. Diabetes Care. 2019;42(Supplement 1):S13.

27. Johansen NB, Vistisen D, Brunner EJ, Tabák AG, Shipley MJ, Wilkinson IB, et al. Determinants of aortic stiffness: 16-year follow-up of the Whitehall II study. PloS one. 2012;7(5). 28. Gabir MM, Hanson RL, Dabelea D, Imperatore G, Roumain J, Bennett PH, et al. The 1997 American Diabetes Association and 1999 World Health Organization criteria for hyperglycemia in the diagnosis and prediction of diabetes. Diabetes Care. 2000;23(8):1108.

29. World Health Organization. Definition and diagnosis of diabetes mellitus and intermediate hyperglycaemia: report of a WHO/IDF consultation. 2006. Report No.: 9241594934.

30. Singer JD, Willett JB, Willett JB. Applied longitudinal data analysis: Modeling change and event occurrence: Oxford university press; 2003.

31. Sacha J. Why should one normalize heart rate variability with respect to average heart rate. Front Physiol. 2013;4:306-.

32. Monfredi O, Lyashkov AE, Johnsen AB, Inada S, Schneider H, Wang R, et al. Biophysical characterization of the underappreciated and important relationship between heart rate variability and heart rate. Hypertension (Dallas, Tex : 1979). 2014;64(6):1334-43.

33. Meyer C, Milat F, McGrath BP, Cameron J, Kotsopoulos D, Teede HJ. Vascular dysfunction and autonomic neuropathy in Type 2 diabetes. Diabetic medicine. 2004;21(7):746-51. 34. Liatis S, Alexiadou K, Tsiakou A, Makrilakis K, Katsilambros N, Tentolouris N. Cardiac Autonomic Function Correlates with Arterial Stiffness in the Early Stage of Type 1 Diabetes. Experimental Diabetes Research. 2011;2011:957901.

35. Mangoni AA, Mircoli L, Giannattasio C, Mancia G, Ferrari AU. Effect of sympathectomy on mechanical properties of common carotid and femoral arteries. Hypertension (Dallas, Tex : 1979). 1997;30(5):1085-8. 
medRxiv preprint doi: https://doi.org/10.1101/2022.02.24.22271384; this version posted February 25, 2022. The copyright holder for this preprint (which was not certified by peer review) is the author/funder, who has granted medRxiv a license to display the preprint in perpetuity.

All rights reserved. No reuse allowed without permission.

36. Mircoli L, Mangoni AA, Giannattasio C, Mancia G, Ferrari AU. Heart rate-dependent stiffening of large arteries in intact and sympathectomized rats. Hypertension (Dallas, Tex : 1979). 1999;34(4 Pt 1):598-602.

37. Giannoglou GD, Chatzizisis YS, Zamboulis C, Parcharidis GE, Mikhailidis DP, Louridas GE. Elevated heart rate and atherosclerosis: an overview of the pathogenetic mechanisms. International journal of cardiology. 2008;126(3):302-12.

38. Park B-J, Lee H-R, Shim J-Y, Lee J-H, Jung D-H, Lee Y-J. Association between resting heart rate and arterial stiffness in Korean adults. Archives of cardiovascular diseases. 2010;103(4):246-52.

39. Hulman A, Simmons RK, Brunner EJ, Witte DR, Færch K, Vistisen D, et al. Trajectories of glycaemia, insulin sensitivity and insulin secretion in South Asian and white individuals before diagnosis of type 2 diabetes: a longitudinal analysis from the Whitehall II cohort study.

Diabetologia. 2017;60(7):1252-60. 
medRxiv preprint doi: https://doi.org/10.1101/2022.02.24.22271384; this version posted February 25, 2022. The copyright holder for this preprint (which was not certified by peer review) is the author/funder, who has granted medRxiv a license to display the preprint in perpetuity.

All rights reserved. No reuse allowed without permission.

\section{Tables and figures}

\begin{tabular}{|c|c|c|c|c|}
\hline & Phase 5 & Phase 7 & Phase 9 & Phase 11 \\
\hline \multicolumn{5}{|l|}{ Participation, N (\%) } \\
\hline Participated & $4715(96.2)$ & $4681(95.5)$ & $4870(99.4)$ & 4649 (94.9) \\
\hline Died before participation & $0(0)$ & $0(0)$ & $0(0)$ & $92(1.8)$ \\
\hline $\begin{array}{r}\text { Non-response } \\
/ \text { withdrawal } \\
\end{array}$ & $186(4.1)$ & $220(4.5)$ & $31(0.6)$ & $160(3.3)$ \\
\hline \multicolumn{5}{|l|}{ Sex, N (\%) } \\
\hline Men & $3479(73.8)$ & $3461(73.9)$ & $3590(73.7)$ & $3431(73.8)$ \\
\hline Women & $1236(26.2)$ & $1220(26.1)$ & $1280(26.3)$ & $1218(26.2)$ \\
\hline \multicolumn{5}{|l|}{ Ethnicity, N (\%) } \\
\hline White & $4364(92.6)$ & $4334(92.3)$ & $4500(92.4)$ & $4317(92.9)$ \\
\hline Non-white & $351(7.4)$ & 347 (7.4) & $470(7.6)$ & $332(7.1)$ \\
\hline Age (years) & $54.0(50.2 ; 59.6)$ & $59.5(55.6 ; 65.1)$ & $64.4(60.5 ; 70.0)$ & $68.5(64.7 ; 74.1)$ \\
\hline BMI & $25.4(23.4 ; 27.7)$ & $25.9(23.7 ; 28.2)$ & $25.9(23.7 ; 28.5)$ & $25.9(23.6 ; 28.6)$ \\
\hline \multicolumn{5}{|l|}{ Socioeconomic status N (\%) } \\
\hline Administrative & $1696(36.0)$ & $1687(36.0)$ & $1744(35.8)$ & $1695(36.5)$ \\
\hline Professional/ Executive & $2418(51.3)$ & $2398(51.2)$ & $2498(51.3)$ & $2380(51.2)$ \\
\hline Clerical/ Support & $601(12.7)$ & $596(12.7)$ & $628(12.9)$ & $574(12.3)$ \\
\hline \multicolumn{5}{|l|}{ Health behaviour determinants } \\
\hline \multicolumn{5}{|l|}{ Smoking N (\%) } \\
\hline Never & $2326(51.3)$ & $2332(50.2)$ & $2371(48.9)$ & $2142(47.5)$ \\
\hline Former & $1844(40.7)$ & $2001(43.0)$ & $2229(46.0)$ & $2224(49.3)$ \\
\hline Current & $364(8.0)$ & $316(6.8)$ & $248(5.1)$ & $142(3.1)$ \\
\hline Alcohol units per week & $10(4.0 ; 20)$ & $9(3.0 ; 18.0)$ & $8(2.0 ; 15.0)$ & $7(2.0 ; 14.0)$ \\
\hline $\begin{array}{l}\text { Physical Activity hours/week } \\
\text { moderate - vigorous physical } \\
\text { activity }\end{array}$ & $12.4(4.4 ; 23.1)$ & $13.5(5.2 ; 24.7)$ & $12.8(4.9 ; 24.9)$ & $12.8(4.5 ; 24.7)$ \\
\hline \multicolumn{5}{|l|}{ Blood measurements } \\
\hline HDL cholesterol (mmol/L) & $1.5(1.2 ; 1.7)$ & $1.6(1.3 ; 1.8)$ & $1.5(1.3 ; 1.9)$ & $1.6(1.3 ; 1.9)$ \\
\hline LDL cholesterol $(\mathrm{mmol} / \mathrm{L})$ & $3.8(3.2 ; 4.4)$ & $3.5(2.9 ; 4.1)$ & $3.0(2.3 ; 3.7)$ & $2.8(2.2 ; 3.5)$ \\
\hline Total cholesterol $(\mathrm{mmol} / \mathrm{L})$ & $5.8(5.2 ; 6.5)$ & $5.7(5.0 ; 6.4)$ & $5.2(4.5 ; 5.9)$ & $5.1(4.3 ; 5.8)$ \\
\hline Triglycerides $(\mathrm{mmol} / \mathrm{L})$ & $1.1(0.8 ; 1.4)$ & $1.1(0.8 ; 1.6)$ & $1.0(0.8 ; 1.5)$ & $1.0(0.8 ; 1.4)$ \\
\hline HbA1c (\%) & - & $5.2(5.0 ; 5.5)$ & $5.6(5.4 ; 5.9)$ & $5.7(5.5 ; 6.0)$ \\
\hline Glucose: fasting $(\mathrm{mmol} / \mathrm{L})$ & $5.0(4.7 ; 5.4)$ & $5.2(4.9 ; 5.6)$ & $5.1(4.8 ; 5.5)$ & $5.2(4.9 ; 5.6)$ \\
\hline $\begin{array}{r}\text { Systolic blood pressure } \\
(\mathrm{mmHg})\end{array}$ & $\begin{array}{l}120.0(110.3 ; \\
131.0)\end{array}$ & $\begin{array}{l}126.0(115.0 \\
136.0)\end{array}$ & $\begin{array}{l}123.5(113.5 ; \\
134.0)\end{array}$ & $\begin{array}{l}126.0(116.0 ; \\
137.0)\end{array}$ \\
\hline $\begin{array}{r}\text { Diastolic blood pressure } \\
(\mathrm{mmHg})\end{array}$ & $77.0(70.0 ; 84.0)$ & $73.0(67.0 ; 80.0)$ & $70.5(63.5 ; 77.0)$ & $70.5(64.0 ; 77.0)$ \\
\hline \multicolumn{5}{|l|}{ Exposure } \\
\hline rHR (resting bpm) & $67.7(61.3 ; 75.1)$ & $66.4(59.6 ; 73.6)$ & $66.2(59.3 ; 73.6)$ & - \\
\hline SDNN (ms) & $35.4(26.6 ; 46.2)$ & $33.9(25.8 ; 44.7)$ & $30.0(22.2 ; 40.5)$ & - \\
\hline $\mathrm{cSDNN}(\mathrm{cv})$ & $3.9(3.1 ; 5.0)$ & $3.7(2.5 ; 4.8)$ & $3.3(2.5 ; 4.3)$ & - \\
\hline RMSSD (ms) & $21.0(14.1 ; 29.9)$ & $20.6(14.0 ; 30.4)$ & $17.8(12.0 ; 27.3)$ & - \\
\hline cRMSSD (cv) & $2.33(1.68 ; 3.23)$ & $2.23(1.59 ; 3.16)$ & $1.92(1.37 ; 2.86)$ & - \\
\hline $\mathrm{LF}\left(\mathrm{ms}^{2}\right)$ & $\begin{array}{l}334.1(178.0 \\
608.111)\end{array}$ & $\begin{array}{l}286(158.5 \\
527.8)\end{array}$ & $\begin{array}{l}224.4(115.7 ; \\
\quad 448.8)\end{array}$ & - \\
\hline cLF (cv) & $4.24(2.34 ; 7.18)$ & $3.49(1.95 ; 6.15)$ & $2.70(1.42 ; 5.19)$ & - \\
\hline $\mathrm{HF}\left(\mathrm{ms}^{2}\right)$ & $\begin{array}{l}224.4(65.6 ; \\
265.6)\end{array}$ & $117(57.3 ; 242.6)$ & $88.2(42.6 ; 191.1)$ & - \\
\hline $\mathrm{cHF}(\mathrm{cv})$ & $1.69(0.87 ; 3.18)$ & $1.37(0.73 ; 2.71)$ & $1.06(0.54 ; 2.15)$ & - \\
\hline
\end{tabular}


medRxiv preprint doi: https://doi.org/10.1101/2022.02.24.22271384; this version posted February 25, 2022. The copyright holder for this preprint (which was not certified by peer review) is the author/funder, who has granted medRxiv a license to display the preprint in perpetuity.

All rights reserved. No reuse allowed without permission.

\begin{tabular}{|c|c|c|c|c|}
\hline \multicolumn{5}{|l|}{ Outcome } \\
\hline $\mathrm{PWV}(\mathrm{m} / \mathrm{s})$ & - & - & $8.04(7.02 ; 9.44)$ & $8.53(7.31 ; 10.27)$ \\
\hline \multicolumn{5}{|l|}{ Disease } \\
\hline \multicolumn{5}{|l|}{ CVD, N (\%) } \\
\hline Yes & $423(8.7)$ & $409(8.5)$ & $476(9.5)$ & $404(8.4)$ \\
\hline No & $4449(91.3)$ & $4449(91.5)$ & $4547(90.5)$ & $4402(91.6)$ \\
\hline \multicolumn{5}{|l|}{ Diabetes, N (\%) } \\
\hline Yes & $272(5.7)$ & $337(7.2)$ & $483(9.9)$ & $389(8.4)$ \\
\hline No & $4444(94.3)$ & $4344(92.8)$ & $4387(90.1)$ & $4260(91.6)$ \\
\hline \multicolumn{5}{|l|}{ Medication } \\
\hline \multicolumn{5}{|l|}{$\begin{array}{l}\text { Anti-hypertensive } \\
\text { medication, } \mathrm{N}(\%)\end{array}$} \\
\hline Yes & $476(10.2)$ & $950(20.4)$ & $1598(32.8)$ & $1880(40.4)$ \\
\hline No & $4206(89.8)$ & $3712(79.6)$ & $3268(67.2)$ & $2768(59.6)$ \\
\hline \multicolumn{5}{|l|}{ CVD medication, N (\%) } \\
\hline Yes & $602(12.9)$ & $1202(25.8)$ & $2391(49.1)$ & $2693(57.9)$ \\
\hline No & $4080(87.1)$ & $3460(74.2)$ & $2475(50.9)$ & $1955(42.1)$ \\
\hline \multicolumn{5}{|l|}{$\begin{array}{l}\text { Glucose lowering medication, } \\
\mathrm{N}(\%)\end{array}$} \\
\hline Yes & $51(1.1)$ & $110(2.4)$ & $188(3.9)$ & $287(6.2)$ \\
\hline No & $4631(98.9)$ & $4552(97.6)$ & $4678(96.1)$ & $4361(93.8)$ \\
\hline \multicolumn{5}{|c|}{$\begin{array}{l}\text { Characteristics describes the population who are participating in each phase } \\
\text { Categorical data shown in } \mathrm{N}(\%) \\
\text { Continuous data shown in median }\left(25^{\text {th }} \text { percentile; } 75^{\text {th }} \text { percentile }\right)\end{array}$} \\
\hline
\end{tabular}


medRxiv preprint doi: https://doi.org/10.1101/2022.02.24.22271384; this version posted February 25, 2022. The copyright holder for this preprint (which was not certified by peer review) is the author/funder, who has granted medRxiv a license to display the preprint in perpetuity.

All rights reserved. No reuse allowed without permission.

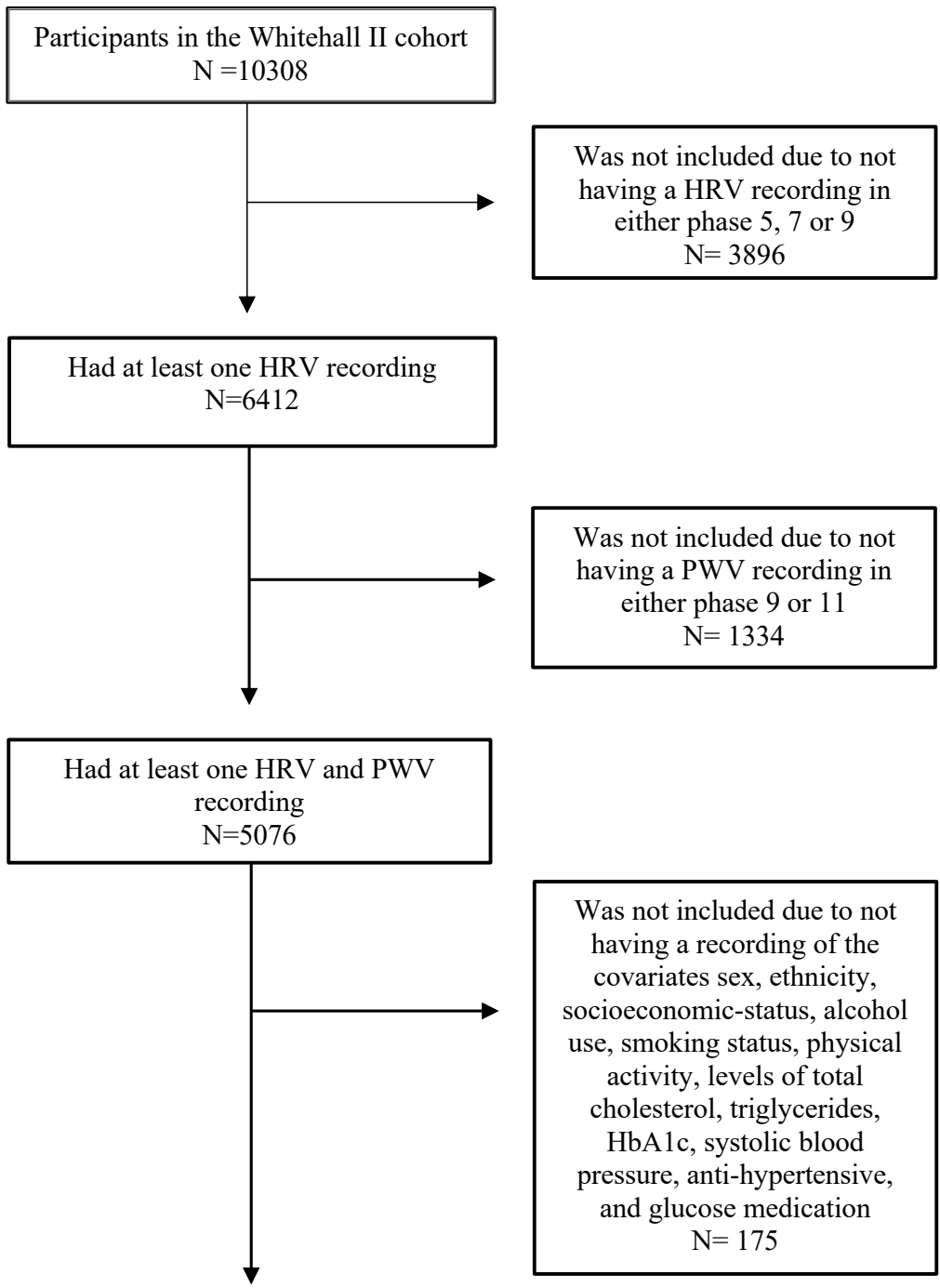

Total included study population $\mathrm{N}=4901$

Figure 1: Flowchart of the included study population 
medRxiv preprint doi: https://doi.org/10.1101/2022.02.24.22271384; this version posted February 25, 2022. The copyright holder for this preprint (which was not certified by peer review) is the author/funder, who has granted medRxiv a license to display the preprint in

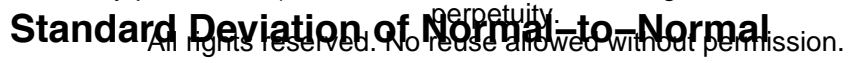
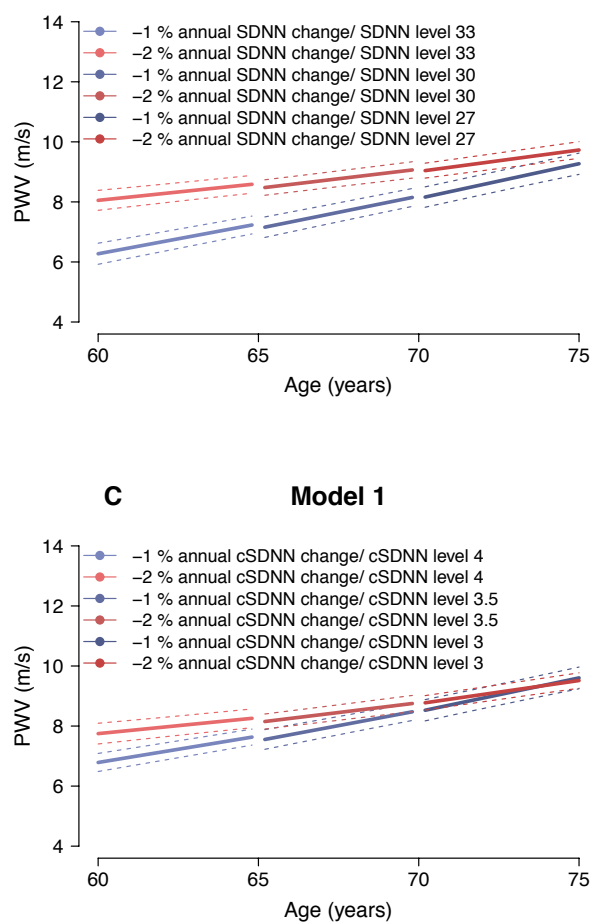

Model 2

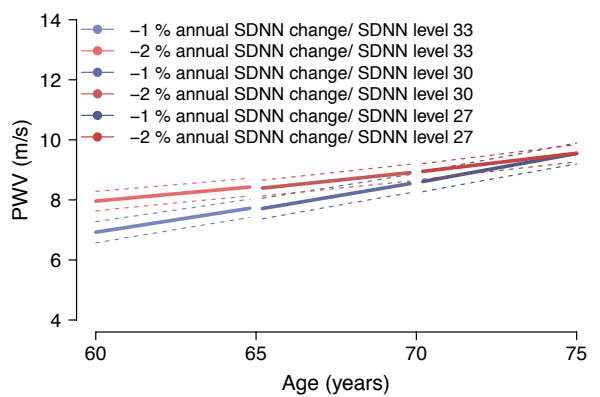

D

Model 2

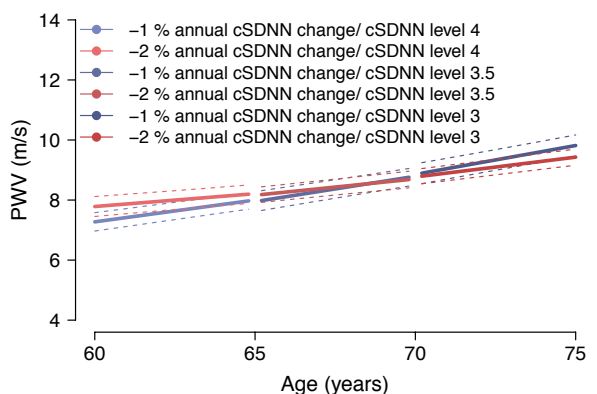

Model 2

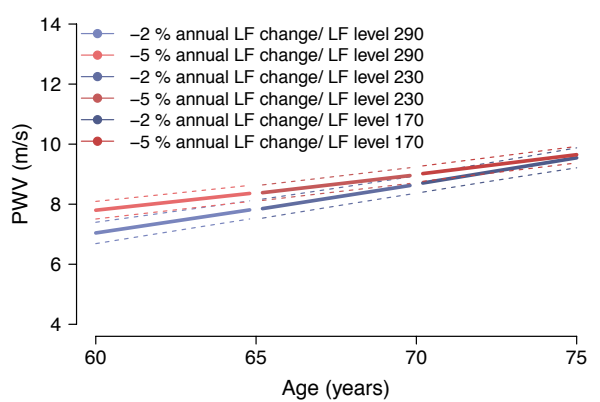

H

Model 2

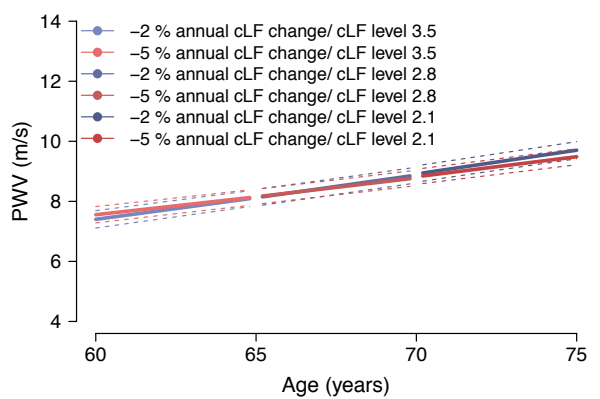

Figur 2: 5-years PWV trajectories association with changes in HRV indices that mainly are characterized by mixed sympathetic and parasympathetic influences (SDNN and LF). The dotted lines show 95\% confidence interval. A) Model 1: PWV trajectories for individuals with either $-1 \%$ or $-2 \%$ annual SDNN decrease B) Model 2: PWV trajectories for individuals with either $-1 \%$ or $-2 \%$ annual SDNN decrease C) Model 1: PWV trajectories for individuals with either $-1 \%$ or $-2 \%$ annual cSDNN decrease D) Model 2: PWV trajectories for individuals with either $1 \%$ or $-2 \%$ annual cSDNN decrease. E) Model 1: PWV trajectories for individuals with either $-2 \%$ or $-5 \%$ annual LF decrease F) Model 2: PWV trajectories for individuals with either $-2 \%$ or $-5 \%$ annual LF decrease G) Model 1: PWV trajectories for individuals with either $-2 \%$ or $-5 \%$ annual cLF decrease $\mathrm{H}$ ) Model 2: PWV trajectories for individuals with either $-2 \%$ or $-5 \%$ annual cLF decrease. Model $1(\mathrm{Sex}=\mathrm{Men}$, Ethnicity= White), Model 2 (Sex=Male, Ethnicity=. 
medRxiv preprint doi: https://doi.org/10.1101/2022.02.24.22271384; this version posted February 25, 2022. The copyright holder for this preprint (which was not certified by peer review) is the author/funder, who has granted medRxiv a license to display the preprint in perpetuity.

All rights reserved. No reuse allowed without permission.

White, $\mathrm{SES}=$ Professional/executive, $\mathrm{BMI}=25$, Smoking status $=$ Non-smoker, Alcohol use $=8$ units per week, Physical activity $=13$ hours weekly of moderate to vigorous, Total cholesterol $=5.2 \mathrm{mmol} / \mathrm{L}$, Triglycerides $=1 \mathrm{mmol} / \mathrm{L}, \mathrm{HbA} 1 \mathrm{c}=$ $5.6 \%$, Systolic blood pressure $=124 \mathrm{mmHg}$, Antihypertensive medication $=$ Not using, Glucose lowering medication $=$ Not using) 
medRxiv preprint doi: https://doi.org/10.1101/2022.02.24.22271384; this version posted February 25, 2022. The copyright holder for this preprint (which was not certified by peer review) is the author/funder, who has granted medRxiv a license to display the preprint in

\section{Root Mean Square Sucbessive Difference}

A

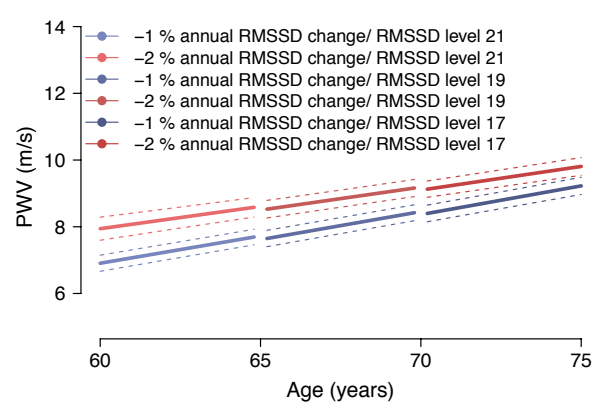

C

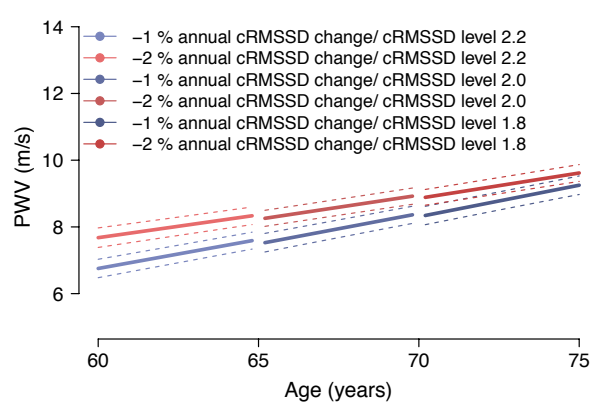

Model 2

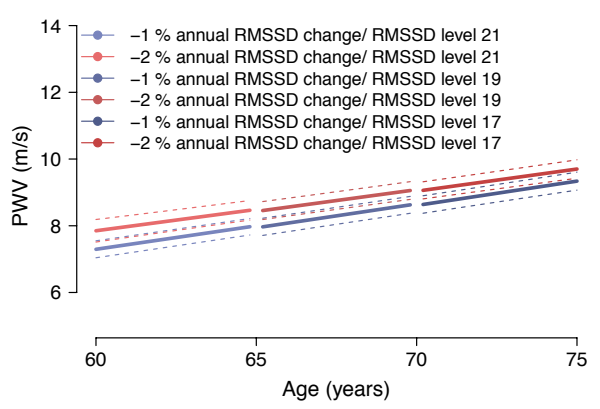

D

Model 2

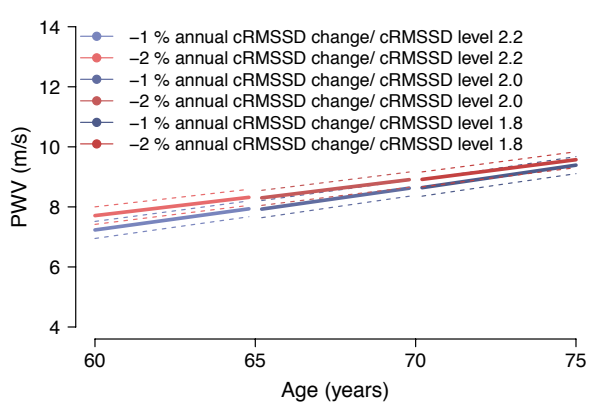

High Frequency

E

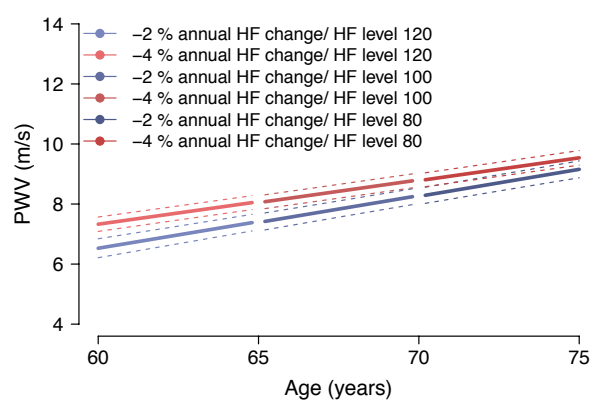

G

Model 1

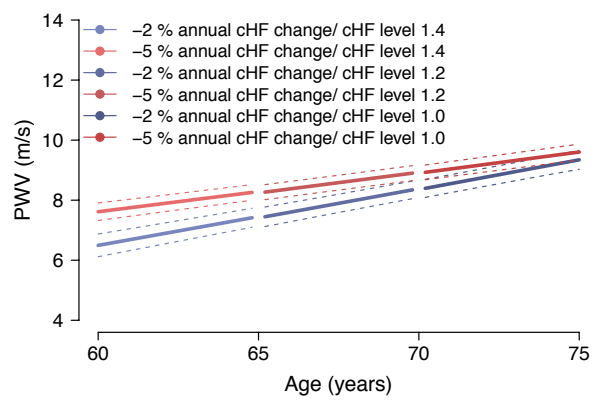

Model 2

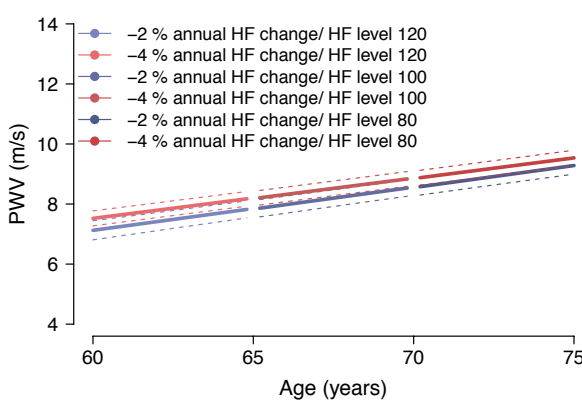

H

Model 2

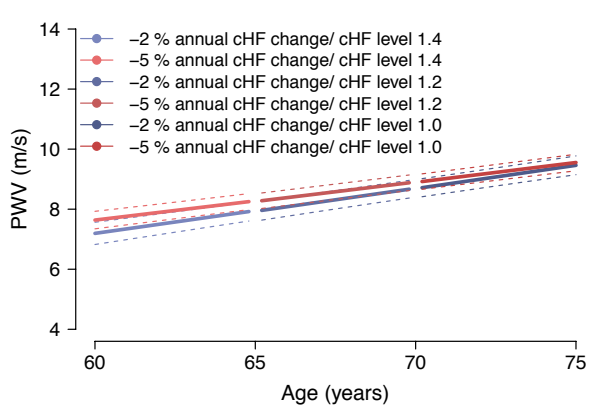

Figure 3: 5-years PWV trajectories and its association with changes in HRV indices that mainly are characterized by parasympathetic influence (RMSSD and HF). The typical individuals have a baseline starting at 60, 65 or 70, respectively. The dotted lines show 95\% confidence interval. A) Model 1: PWV trajectories for individuals with either $1 \%$ or $-2 \%$ annual RMSSD decrease B) Model 2: PWV trajectories for individuals with either $-1 \%$ or $-2 \%$ annual RMSSD decrease C) Model 1: PWV trajectories for individuals with either $-1 \%$ or $-2 \%$ annual cRMSSD decrease D) Model 2: PWV trajectories for individuals with either $-1 \%$ or $-2 \%$ annual cRMSSD decrease E) Model 1: PWV trajectories for individuals with either $-2 \%$ or $-4 \%$ annual HF decrease F) Model 2: PWV trajectories for individuals with either $-2 \%$ or $-4 \%$ annual HF decrease G) Model 1: PWV trajectories for individuals with either $-2 \%$ or $-5 \%$ annual $\mathrm{cHF}$ decrease $\mathrm{H}$ ) Model 2: PWV trajectories for individuals with either $-2 \%$ or $-5 \%$ annual cHF decrease. 
medRxiv preprint doi: https://doi.org/10.1101/2022.02.24.22271384; this version posted February 25, 2022. The copyright holder for this preprint (which was not certified by peer review) is the author/funder, who has granted medRxiv a license to display the preprint in perpetuity.

All rights reserved. No reuse allowed without permission.

Model $1(\mathrm{Sex}=$ Men, Ethnicity $=$ White $)$, Model $2(\mathrm{Sex}=$ Male, Ethnicity $=$. White, $\mathrm{SES}=$ Professional/executive, $\mathrm{BMI}=$ 25, Smoking status $=$ Non-smoker, Alcohol use $=8$ units per week, Physical activity $=13$ hours weekly of moderate to vigorous, Total cholesterol $=5.2 \mathrm{mmol} / \mathrm{L}$, Triglycerides $=1 \mathrm{mmol} / \mathrm{L}, \mathrm{HbA} 1 \mathrm{c}=5.6 \%$, Systolic blood pressure $=124 \mathrm{mmHg}$, Antihypertensive medication= Not using, Glucose lowering medication= Not using)

\section{Resting Heart Rate}
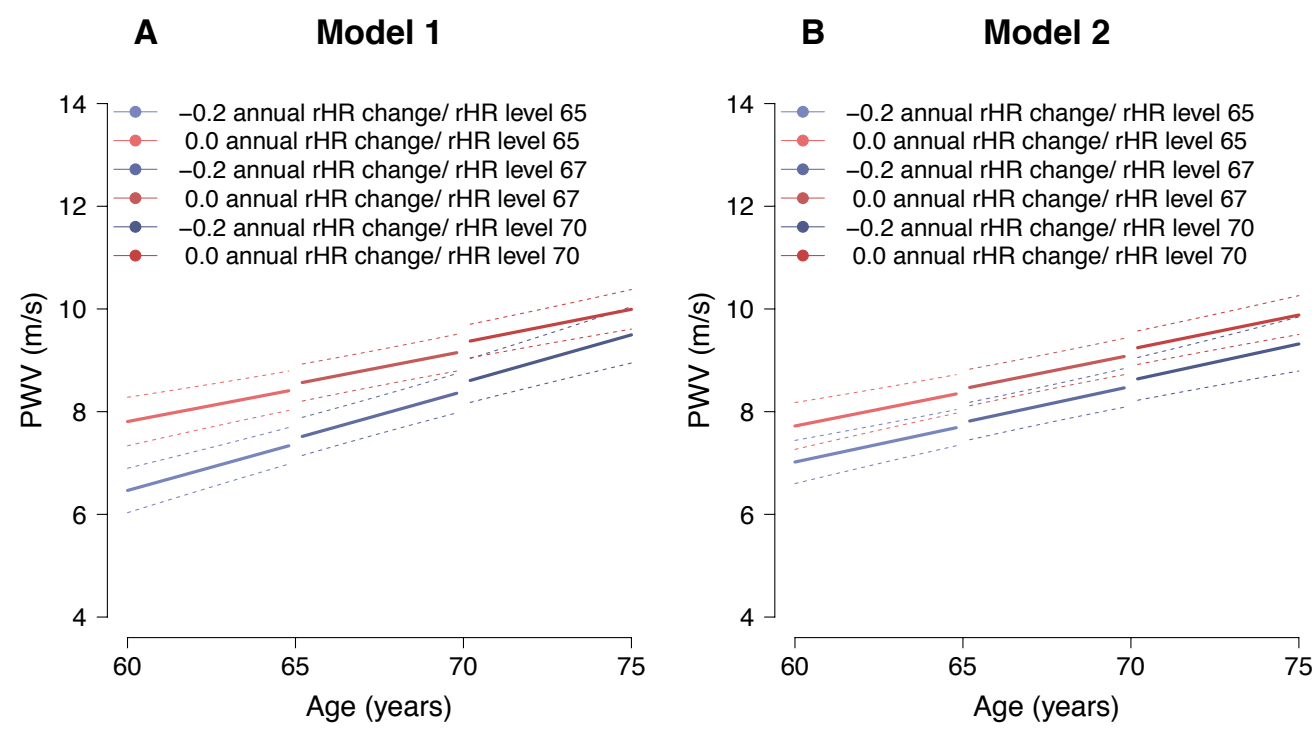

Figure 4: 5-years PWV trajectories and its association with changes in rHR. The typical individuals have baseline age at 60, 65 and 70, respectively. The dotted lines show 95\% confidence interval. The typical individuals have a baseline starting at 60, 65 or 70, respectively. The dotted lines show 95\% confidence interval. A) Model 1: PWV trajectories for individuals with either $0 \%$ or $-0.2 \%$ annual $\mathrm{rHR}$ change B) Model 2: PWV trajectories for individuals with either $0 \%$ or $-0.2 \%$ annual $\mathrm{rHR}$. Model $1(\mathrm{Sex}=\mathrm{Men}$, Ethnicity $=$ White $)$, Model $2(\mathrm{Sex}=$ Male, Ethnicity $=$. White, SES=

Professional/executive, $\mathrm{BMI}=25, \mathrm{Smoking}$ status $=$ Non-smoker, Alcohol use $=8$ units per week, Physical activity $=13$ hours weekly of moderate to vigorous, Total cholesterol $=5.2 \mathrm{mmol} / \mathrm{L}$, Triglycerides $=1 \mathrm{mmol} / \mathrm{L}, \mathrm{HbA} 1 \mathrm{c}=5.6 \%$, Systolic blood pressure $=124 \mathrm{mmHg}$, Antihypertensive medication= Not using, Glucose lowering medication= Not using) 
medRxiv preprint doi: https://doi.org/10.1101/2022.02.24.22271384; this version posted February 25, 2022. The copyright holder for this preprint (which was not certified by peer review) is the author/funder, who has granted medRxiv a license to display the preprint in perpetuity.

All rights reserved. No reuse allowed without permission.

\section{Supplementary material}


medRxiv preprint doi: https://doi.org/10.1101/2022.02.24.22271384; this version posted February 25, 2022. The copyright holder for this preprint (which was not certified by peer review) is the author/funder, who has granted medRxiv a license to display the preprint in

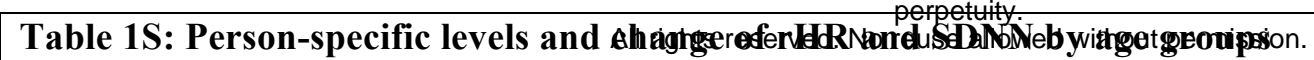

\begin{tabular}{|c|c|c|c|c|}
\hline Exposure & $\mathrm{N}$ & Npe & Levels & Annual change \\
\hline rHR & 4901 & 10249 & & \\
\hline Age $>65$ & 2625 & - & $66.63 \mathrm{bpm}(61.9 ; 72.1)$ & $-0.10(-0.12 ;-0.08)^{1}$ \\
\hline Age $65-70$ & 1057 & - & $66.21 \mathrm{bpm}(61.3 ; 71.6)$ & $-0.10(-0.13 ;-0.07)^{1}$ \\
\hline Age $\geq 70$ & 1219 & - & $66.33 \mathrm{bpm}(61.2 ; 72.1)$ & $-0.10(-0.13 ;-0.06)^{1}$ \\
\hline SDNN & 4901 & 10249 & & \\
\hline Age $>65$ & 2625 & - & $32.9 \mathrm{~ms}(28.5 ; 37.5)$ & $-1.5(-1.8 ;-1.2)^{2}$ \\
\hline Age $65-70$ & 1057 & - & $30.0 \mathrm{~ms}(25.1 ; 35.2)$ & $-1.5(-1.9 ;-1.0)^{2}$ \\
\hline Age $\geq 70$ & 1219 & - & $27.4 \mathrm{~ms}(22.4 ; 33.6)$ & $-1.5(-1.9 ;-1.0)^{2}$ \\
\hline $\mathrm{cSDNN}$ & 4901 & 10249 & & \\
\hline Age $>65$ & 2625 & - & $3.6(3.2 ; 4.1)$ & $-1.6(-1.9 ;-1.3)^{2}$ \\
\hline Age $65-70$ & 1057 & - & $3.3(2.8 ; 3.8)$ & $-1.6(-2.0 ;-1.2)^{2}$ \\
\hline Age $\geq 70$ & 1219 & - & $3.0(2.5 ; 3.6)$ & $-1.6(-2.0 ;-1.1)^{2}$ \\
\hline $\mathrm{LF}$ & 4901 & 10249 & & \\
\hline Age $>65$ & 2625 & - & $274.8 \mathrm{~ms}^{2}(199.0 ; 381.6)$ & $-3.7(-4.4 ;-3.1)^{2}$ \\
\hline Age $65-70$ & 1057 & - & $212.3 \mathrm{~ms}^{2}(139.7 ; 309.4)$ & $-3.7(-4.5 ;-3.0)^{2}$ \\
\hline Age $\geq 70$ & 1219 & - & $174.3 \mathrm{~ms}^{2}(111.4 ; 276.3)$ & $-3.7(-5.0 ;-2.8)^{2}$ \\
\hline $\mathrm{cLF}$ & 4901 & 10249 & & \\
\hline Age $>65$ & 2625 & - & $3.3(2.5 ; 4.6)$ & $-4.0(-4.7 ;-3.2)^{2}$ \\
\hline Age $65-70$ & 1057 & - & $3.3(2.8 ; 3.8)$ & $-4.0(-4.9 ;-3.2)^{2}$ \\
\hline Age $\geq 70$ & 1219 & - & $3.0(2.5 ; 3.6)$ & $-3.9(-4.8 ;-3.0)^{2}$ \\
\hline RMSSD & 4901 & 10249 & & \\
\hline Age $>65$ & 2625 & - & $20.0 \mathrm{~ms}(16.4 ; 24.0)$ & $-1.2(-1.7 ;-0.7)^{2}$ \\
\hline Age $65-70$ & 1057 & - & $18.1 \mathrm{~ms}(14.4 ; 22.3)$ & $-1.2(-1.8 ;-0.7)^{2}$ \\
\hline Age $\geq 70$ & 1219 & - & $17.1 \mathrm{~ms}(12.9 ; 23.4)$ & $-1.2(-1.8 ;-0.5)^{2}$ \\
\hline cRMSSD & 4901 & 10249 & & \\
\hline Age $>65$ & 2625 & - & $2.2(1.9 ; 2.6)$ & $-1.4(-1.9 ;-0.9)^{2}$ \\
\hline Age $65-70$ & 1057 & - & $2.0(1.6 ; 2.4)$ & $-1.4(-1.9 ;-0.8)^{2}$ \\
\hline Age $\geq 70$ & 1219 & - & $1.9(1.5 ; 2.5)$ & $-1.3(-2.0 ;-0.6)^{2}$ \\
\hline $\mathrm{HF}$ & 4901 & 10249 & & \\
\hline Age $>65$ & 2625 & - & $110.6 \mathrm{~ms}^{2}(76.2 ; 161.1)$ & $-3.5(-4.1 ;-2.9)^{2}$ \\
\hline Age $65-70$ & 1057 & - & $87.5 \mathrm{~ms}^{2}(56.3 ; 133.6)$ & $-3.5(-4.3 ;-2.7)^{2}$ \\
\hline Age $\geq 70$ & 1219 & - & $72.0 \mathrm{~ms}^{2}(43.4 ; 123.8)$ & $-3.5(-4.4 ;-2.4)^{2}$ \\
\hline $\mathrm{cHF}$ & 4901 & 10249 & & \\
\hline Age $>65$ & 2625 & - & $1.3(0.9 ; 1.9)$ & $-3.8(-4.4 ;-3.0)^{2}$ \\
\hline Age $65-70$ & 1057 & - & $1.0(0.7 ; 1.6)$ & $-3.8(-4.3 ;-3.0)^{2}$ \\
\hline Age $\geq 70$ & 1219 & - & $0.9(0.5 ; 1.4)$ & $-3.6(-4.5 ;-2.8)^{2}$ \\
\hline \multicolumn{5}{|c|}{$\begin{array}{l}\text { Estimates represent each participant's } \mathrm{rHR} / \mathrm{SDNN} \text { level and annual change at age in phase } 9 \\
\text { Results of the median with }\left(25^{\text {th }} \text { percentile, } 75^{\text {th }} \text { percentile }\right) \\
\mathrm{N} \text {, number of participants used in particular analysis, Npe, number of person examinations used in particular analysis } \\
{ }^{1} \text { Change in bpm per year } \\
{ }^{2} \text { Percentage change in HRV per year }\end{array}$} \\
\hline
\end{tabular}




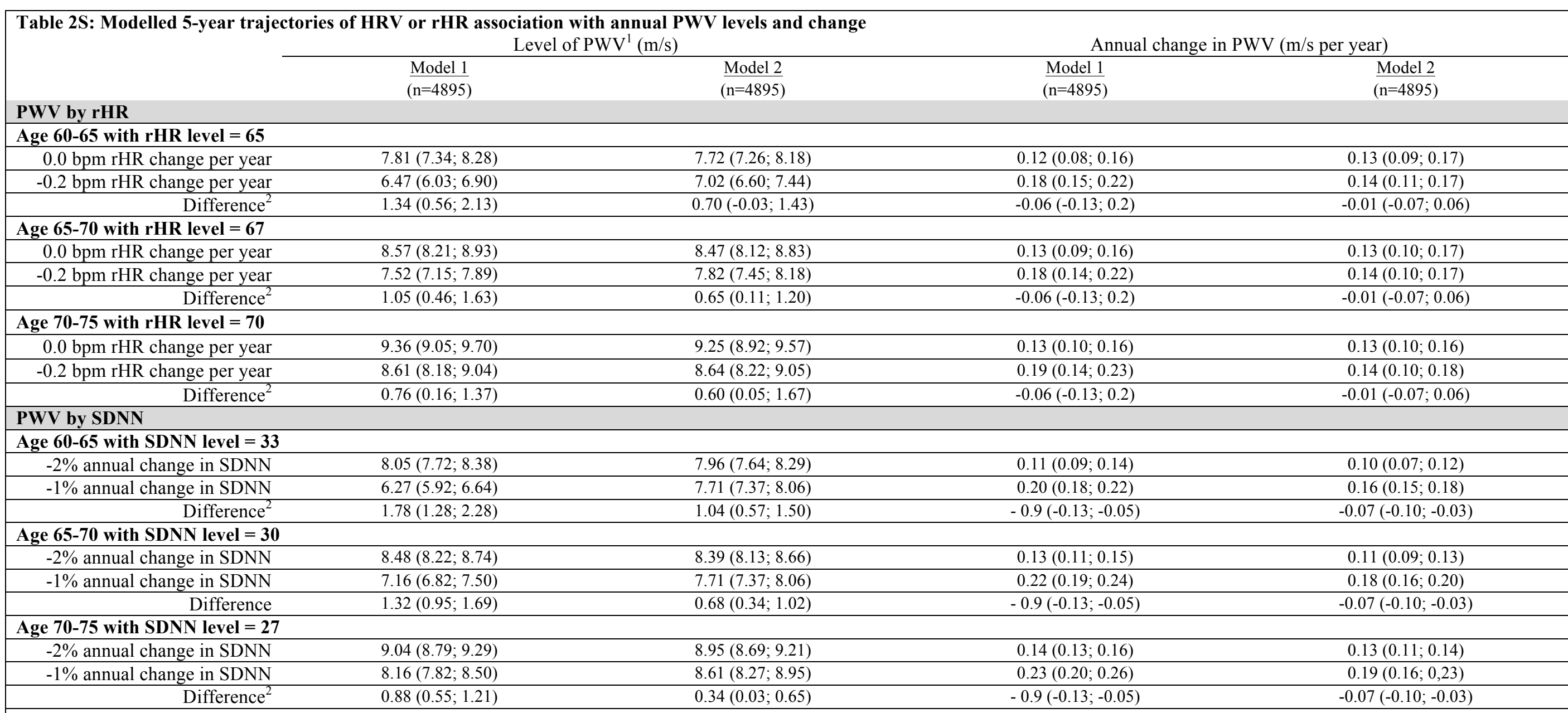

Fixed effect results of level and annual change with $95 \%$ confidence intervals of 5-year trajectories of modelled individuals at age 60,65 and 70 .

Model 1: Sex $=$ Men, Ethnicity $=$ White

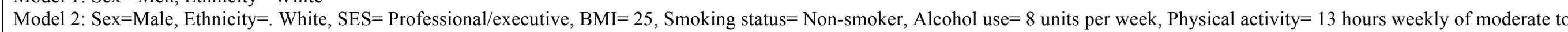

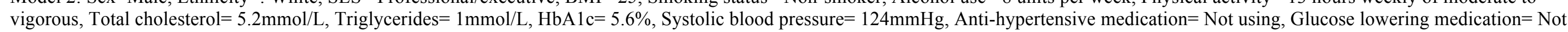
using

${ }^{1}$ Level of PWV represent the participant modelled age at phase 9

${ }^{2}$ PWV level and change difference between two groups with different exposure of change in rHR or SDNN 
medRxiv preprint doi: https://doi.org/10.1101/2022.02.24.22271384; this version posted February 25, 2022. The copyright holder for this preprint (which was not certified by peer review) is the author/funder, who has granted medRxiv a license to display the preprint in perpetuity.

A All rights reserved. No reuse allowed whout permission.
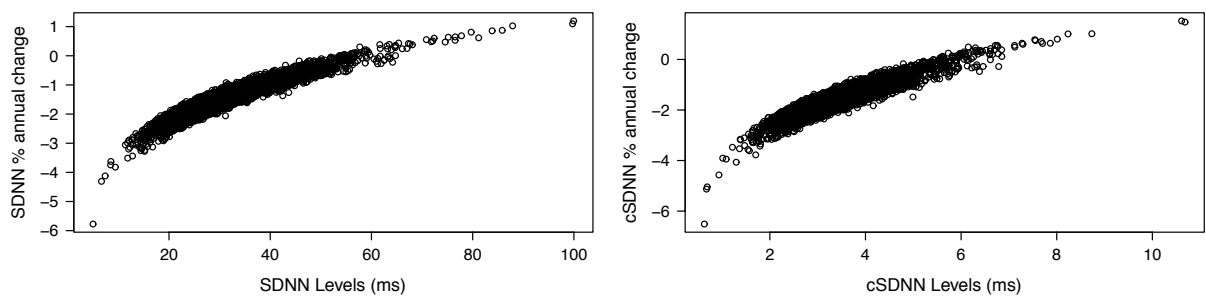

C

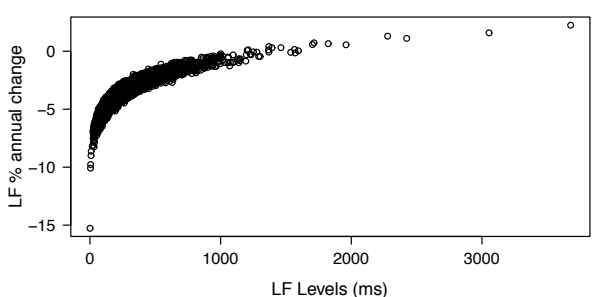

D

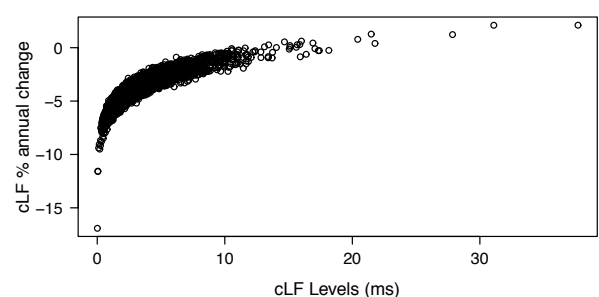

E

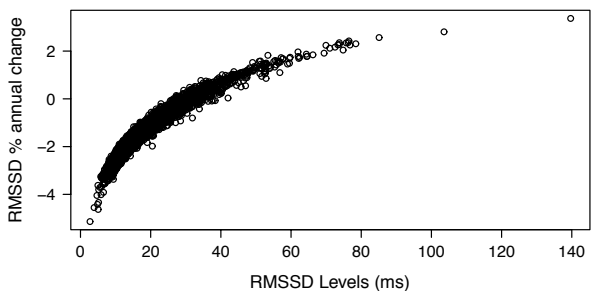

$\mathbf{F}$

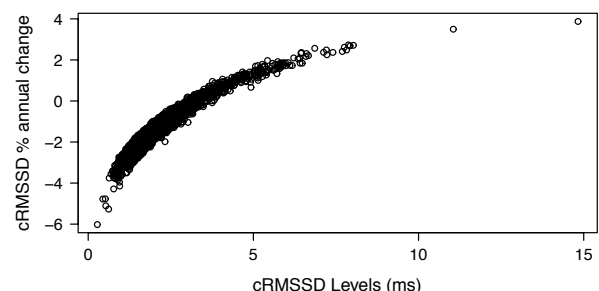

G

H
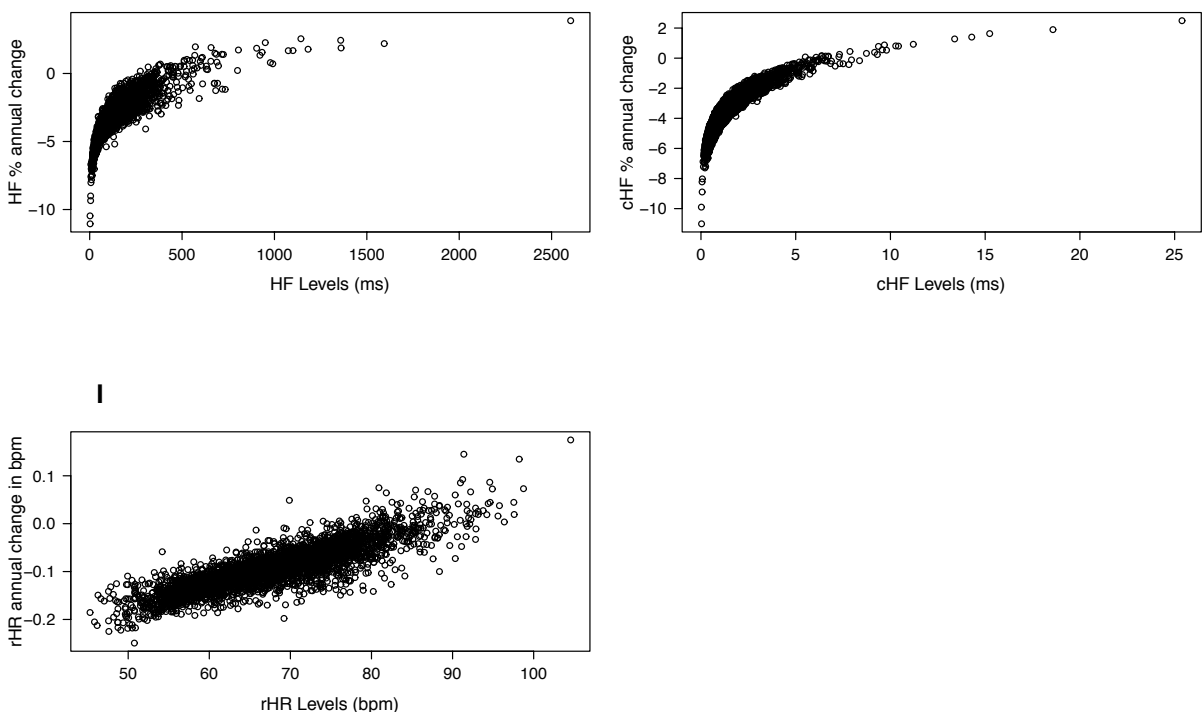

Figure 1S: Plots of the study populations distribution of HRV/rHR level in phase 9 and the HRV percentage annual change/ rHR annual change in bpm. A) SDNN B) cSDNN C) LF D) cLF E) RMSSD F) cRMSSD G) HF H) cHF I) $\mathrm{rHR}$ 
medRxiv preprint doi: https://doi.org/10.1101/2022.02.24.22271384; this version posted February 25, 2022. The copyright holder for this preprint (which was not certified by peer review) is the author/funder, who has granted medRxiv a license to display the preprint in perpetuity.

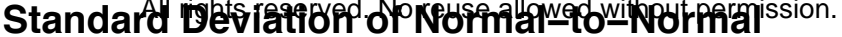

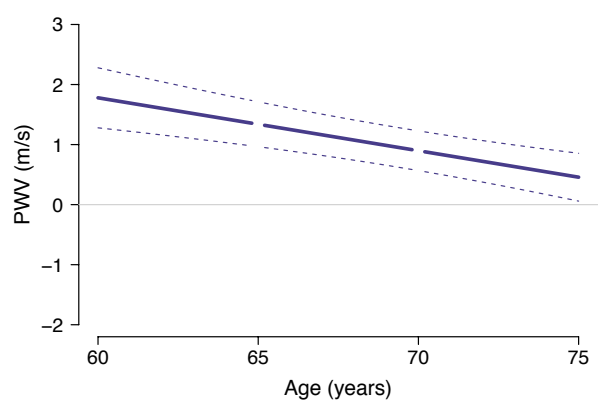

C

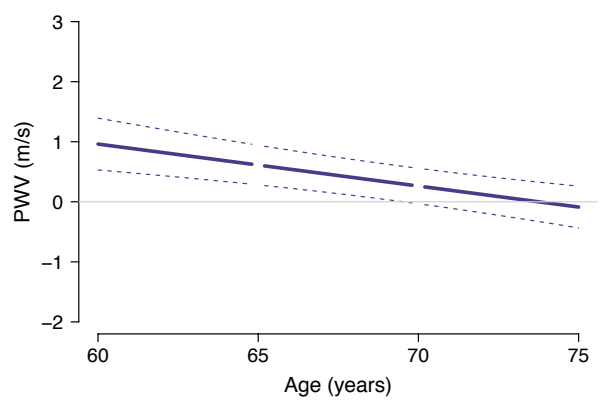

B

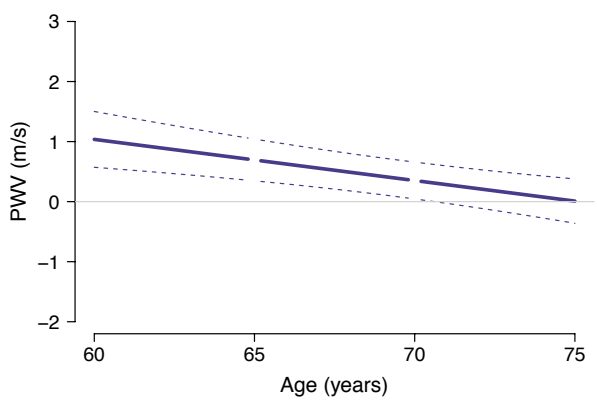

D

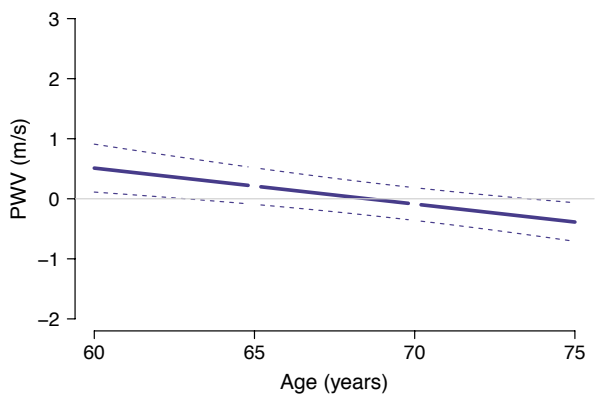

Low Frequency

E

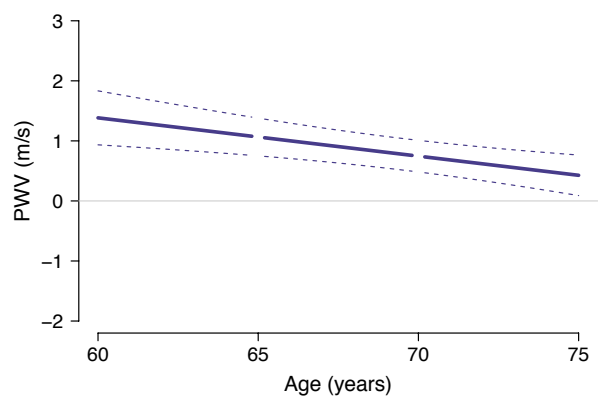

$\mathbf{G}$

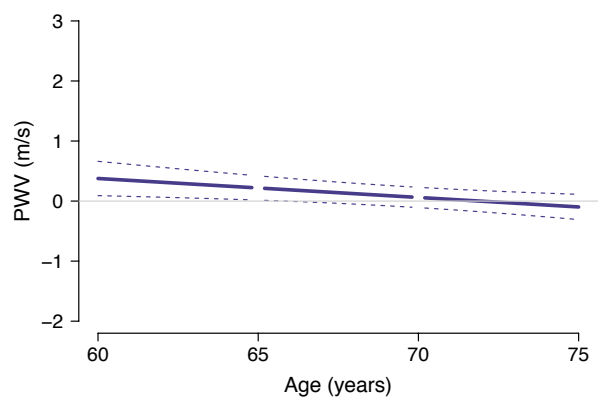

F

Model 2

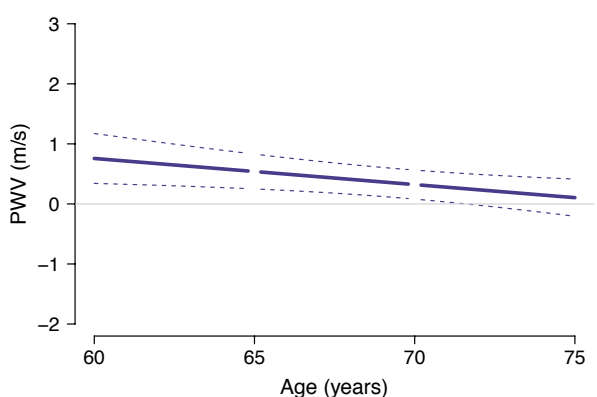

H

Model 2

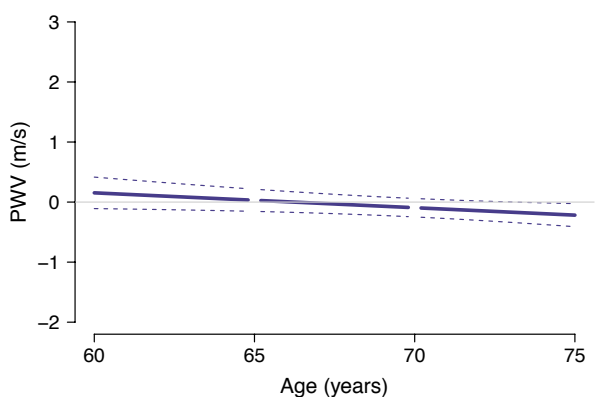

Figure 2S: PWV difference by change in HRV indices that mainly are characterized by mixed sympathetic and parasympathetic influences (SDNN and LF) (difference in each panel in figure 2 in the article). A) Model 1: PWV difference between individuals with $-1 \%$ and $-2 \%$ annual SDNN decrease B) Model 2: PWV difference between individuals with $-1 \%$ and $-2 \%$ annual SDNN decrease C) Model 1: PWV difference between individuals with -1\% and $2 \%$ annual cSDNN decrease D) Model 2: PWV difference between individuals with $-1 \%$ and $-2 \%$ annual cSDNN decrease E) Model 1: PWV difference between individuals with $-2 \%$ and $-5 \%$ annual LF decrease F) Model 2: PWV difference between individuals with $-2 \%$ and $-5 \%$ annual LF decrease G) Model 1: PWV difference between individuals with $-2 \%$ and $-5 \%$ annual cLF decrease $\mathrm{H}$ ) Model 2: PWV difference between individuals with $-2 \%$ and $-5 \%$ annual cLF decrease. The dotted lines show 95\% confidence interval. Model 1 (Sex= Men, Ethnicity= White), Model 2 
medRxiv preprint doi: https://doi.org/10.1101/2022.02.24.22271384; this version posted February 25, 2022. The copyright holder for this preprint (which was not certified by peer review) is the author/funder, who has granted medRxiv a license to display the preprint in All rights reserved. No reuse allowed without permission.

$($ Sex $=$ Male, Ethnicity $=$. White, SES $=$ Professional/executive, $B M I=25$, Smoking status $=$ Non-smoker, Alcohol use $=8$ units per week, Physical activity $=13$ hours weekly of moderate to vigorous, Total cholesterol $=5.2 \mathrm{mmol} / \mathrm{L}$,

Triglycerides $=1 \mathrm{mmol} / \mathrm{L}, \mathrm{HbA} 1 \mathrm{c}=5.6 \%$, Systolic blood pressure $=124 \mathrm{mmHg}$, Antihypertensive medication= Not using, Glucose lowering medication $=$ Not using) 
medRxiv preprint doi: https://doi.org/10.1101/2022.02.24.22271384; this version posted February 25, 2022. The copyright holder for this preprint (which was not certified by peer review) is the author/funder, who has granted medRxiv a license to display the preprint in

\section{Root Mean Square Sureeesisive Difference}

A

Model 1
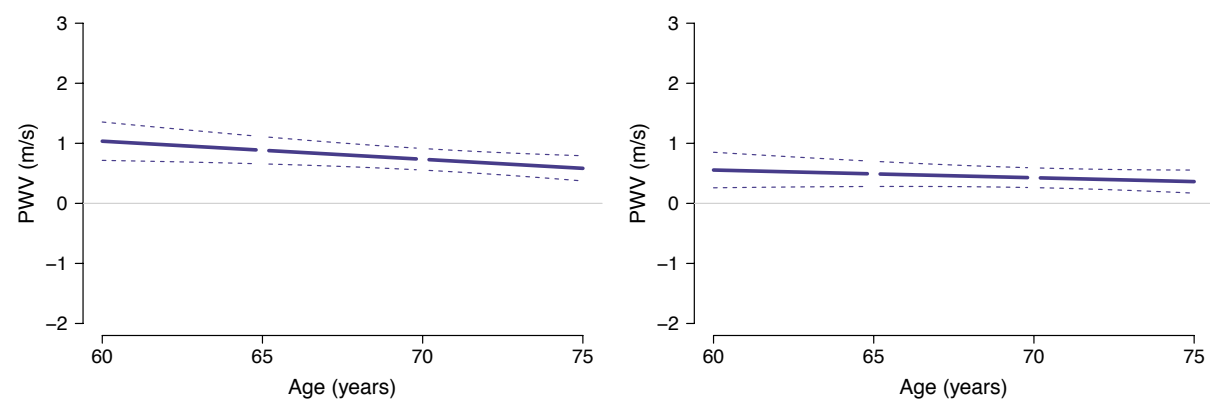

C

Model 1

D

Model 2
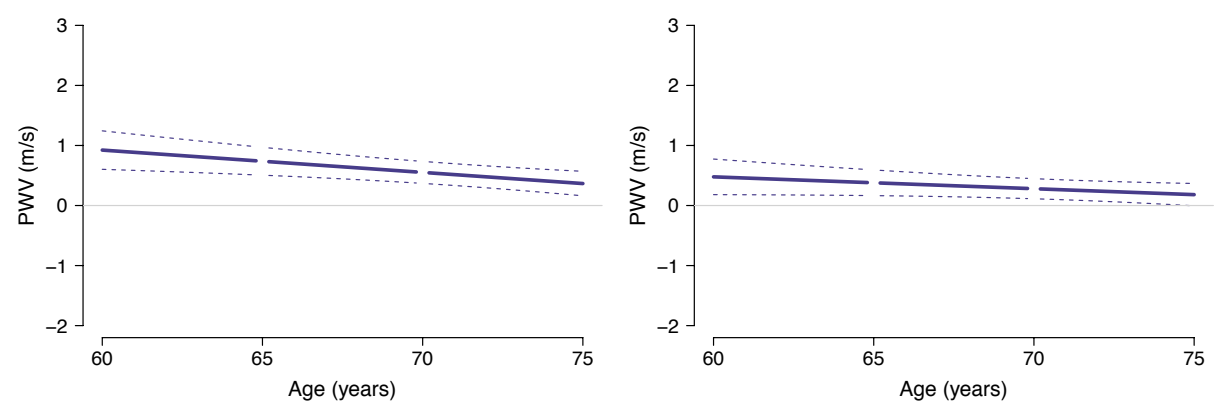

High Frequency

E

Model 1
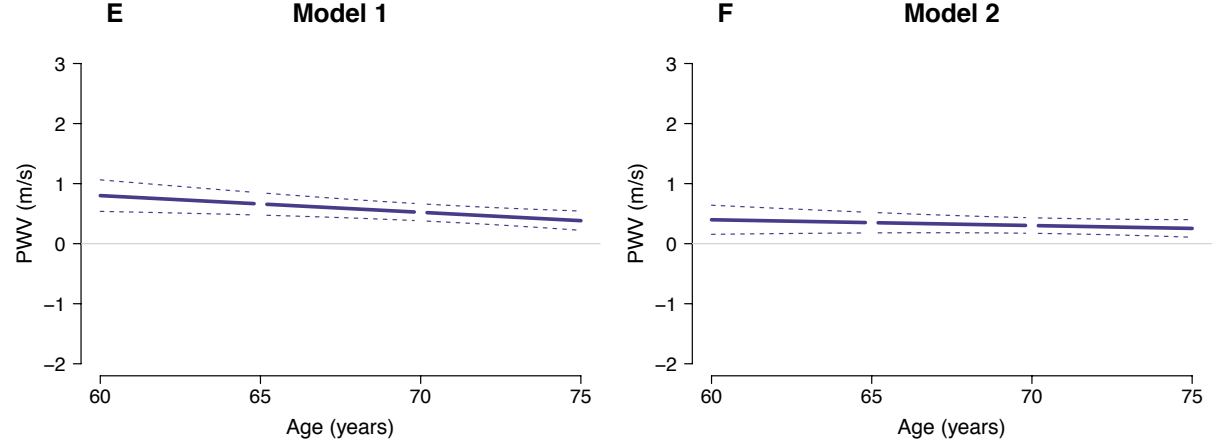

H

Model 2
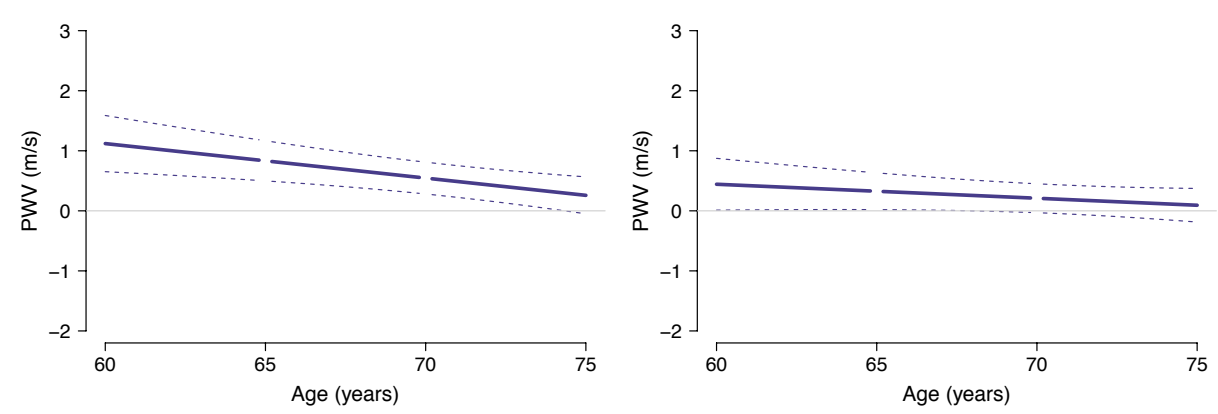

Figure 3S: PWV difference by change in HRV indices that mainly are characterized by parasympathetic influence (RMSSD and HF) (difference in each panel in figure 3 in the article). A) Model 1: PWV difference between individuals with $-1 \%$ and $-2 \%$ annual RMSSD decrease B) Model 2: PWV difference between individuals with $-1 \%$ and $-2 \%$ annual RMSSD decrease C) Model 1: PWV difference between individuals with $-1 \%$ and $-2 \%$ annual cRMSSD decrease D) Model 2: PWV difference between individuals with $-1 \%$ and $-2 \%$ annual cRMSSD decrease E) Model 1 : PWV difference between individuals with $-2 \%$ and $-4 \%$ annual HF decrease F) Model 2: PWV difference between individuals with $-2 \%$ and $-4 \%$ annual HF decrease G) Model 1: PWV difference between individuals with $-2 \%$ and $-5 \%$ annual cHF decrease H) Model 2: PWV difference between individuals with $-2 \%$ and $-5 \%$ annual cHF decrease. The dotted lines show 95\% confidence interval. Model $1(\mathrm{Sex}=\mathrm{Men}$, Ethnicity= White), Model $2(\mathrm{Sex}=\mathrm{Male}, \mathrm{Ethnicity}=$. 
medRxiv preprint doi: https://doi.org/10.1101/2022.02.24.22271384; this version posted February 25, 2022. The copyright holder for this preprint (which was not certified by peer review) is the author/funder, who has granted medRxiv a license to display the preprint in perpetuity.

All rights reserved. No reuse allowed without permission.

White, $\mathrm{SES}=$ Professional/executive, $\mathrm{BMI}=25$, Smoking status $=$ Non-smoker, Alcohol use $=8$ units per week, Physical activity $=13$ hours weekly of moderate to vigorous, Total cholesterol $=5.2 \mathrm{mmol} / \mathrm{L}$, Triglycerides $=1 \mathrm{mmol} / \mathrm{L}, \mathrm{HbA} 1 \mathrm{c}=$ $5.6 \%$, Systolic blood pressure $=124 \mathrm{mmHg}$, Antihypertensive medication $=$ Not using, Glucose lowering medication $=$ Not using)

\section{Resting heart rate}

A

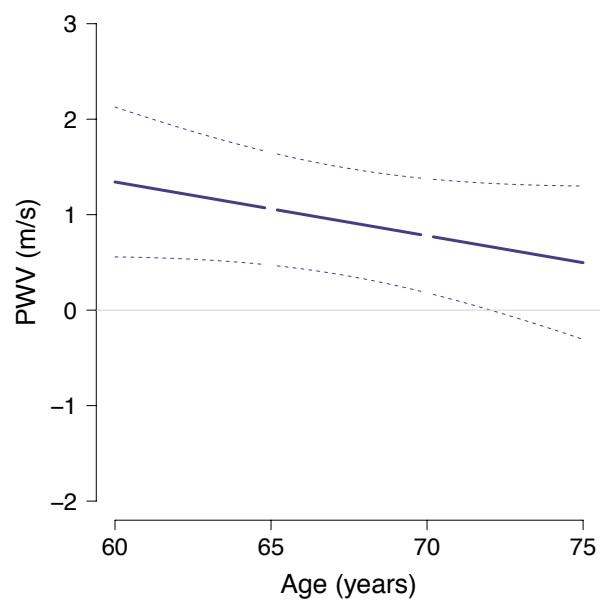

B

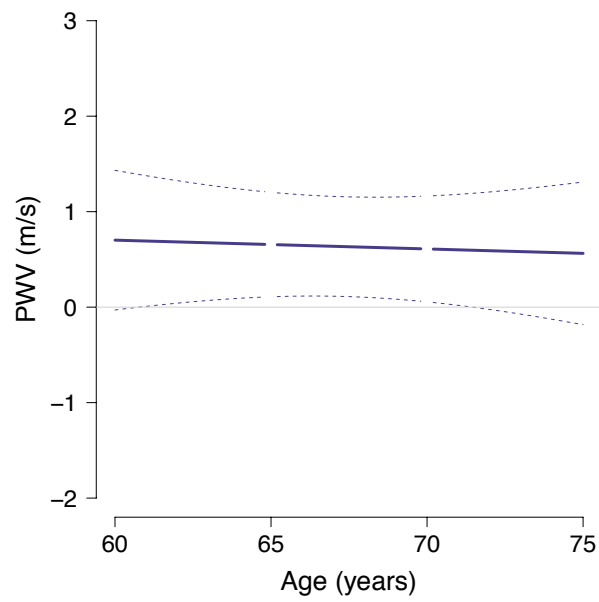

Figure 4S: PWV difference by change in rHR (difference in each panel in figure 4 in the article). A) Model 1: PWV difference between individuals with $0.0 \%$ and $-0.2 \%$ annual $\mathrm{rHR}$ change B) Model 2: PWV difference between individuals with $0 \%$ and $-0.2 \%$ annual $\mathrm{rHR}$ change. The dotted lines show 95\% confidence interval. Model 1 (Sex= Men, Ethnicity= White), Model $2(\mathrm{Sex}=$ Male, Ethnicity=. White, SES= Professional/executive, BMI=25, Smoking status $=$ Non-smoker, Alcohol use $=8$ units per week, Physical activity $=13$ hours weekly of moderate to vigorous, Total cholesterol $=5.2 \mathrm{mmol} / \mathrm{L}$, Triglycerides $=1 \mathrm{mmol} / \mathrm{L}, \mathrm{HbAl}=5.6 \%$, Systolic blood pressure $=124 \mathrm{mmHg}$, Antihypertensive medication= Not using, Glucose lowering medication= Not using) 
medRxiv preprint doi: https://doi.org/10.1101/2022.02.24.22271384; this version posted February 25, 2022. The copyright holder for this preprint (which was not certified by peer review) is the author/funder, who has granted medRxiv a license to display the preprint in

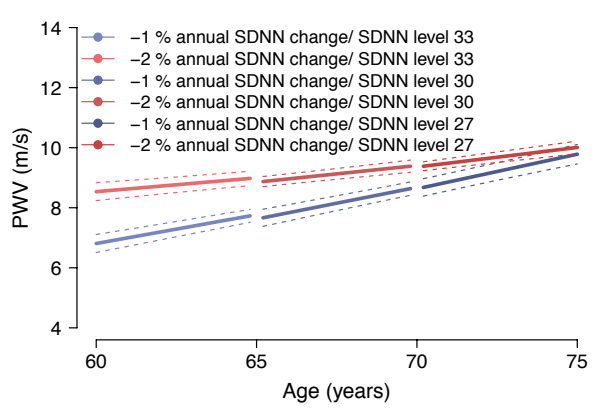

C

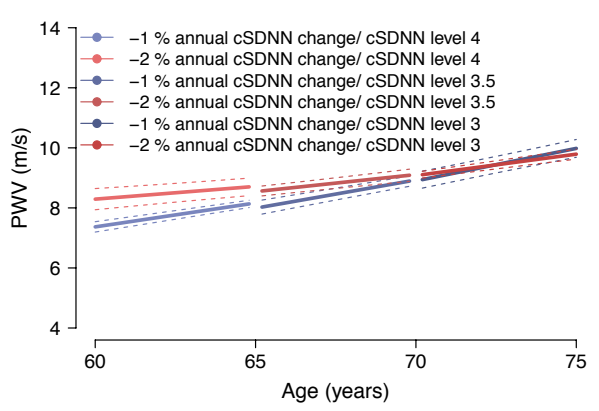

A

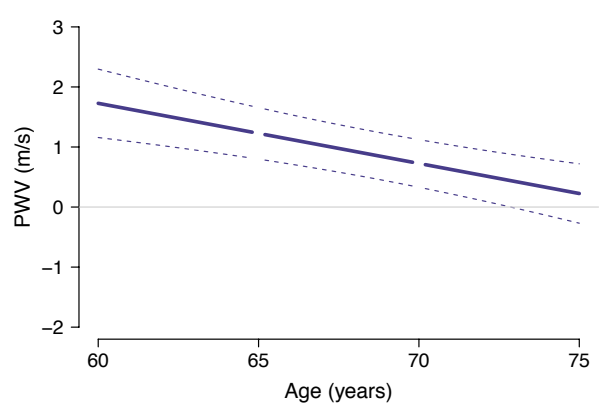

C

Model 1

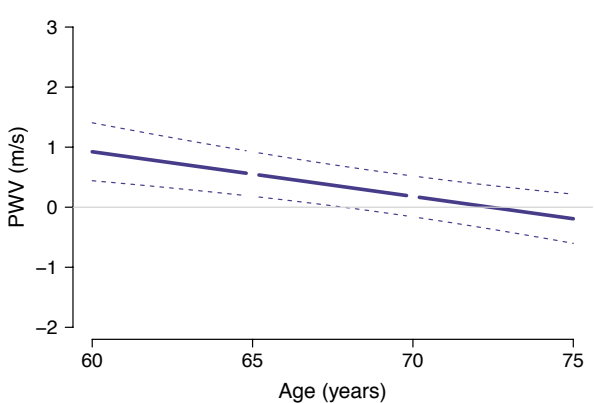

allowed 10

Model 2

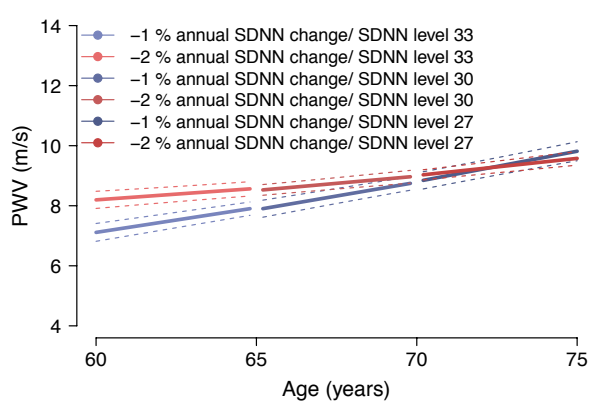

D

Model 2

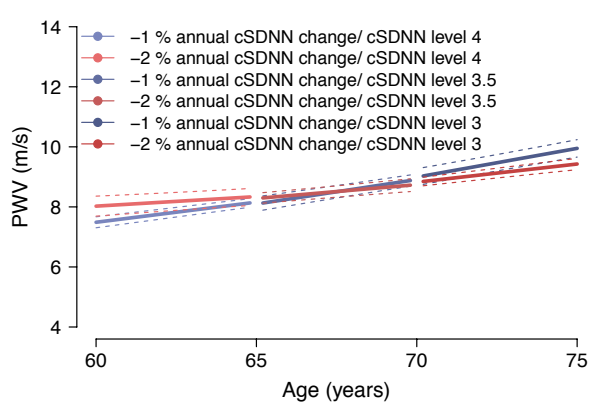

B

Model 2

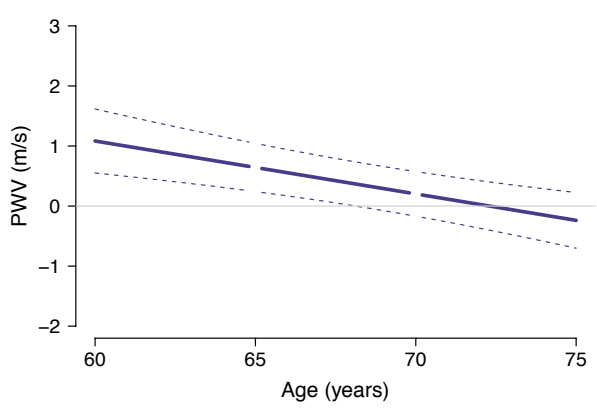

D

Model 2

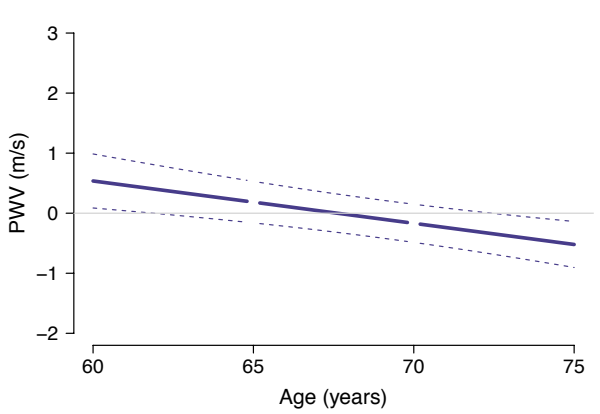

Figure 5S: 5-years PWV trajectories association with changes in SDNN in a subpopulation without diabetes. A) Model 1: PWV trajectories for individuals with either $-1 \%$ or $-2 \%$ annual SDNN decrease B) Model 2: PWV trajectories for individuals with either $-1 \%$ or $-2 \%$ annual SDNN decrease C) Model 1: PWV trajectories for individuals with either $1 \%$ or $-2 \%$ annual cSDNN decrease D) Model 2: PWV trajectories for individuals with either $-1 \%$ or $-2 \%$ annual cSDNN decrease. (The differences between the typical individuals are shown for the corresponding A, B, C, D figures below). The dotted lines show 95\% confidence interval. Model $1(\mathrm{Sex}=\mathrm{Men}$, Ethnicity $=$ White $)$, Model $2(\mathrm{Sex}=\mathrm{Male}$, Ethnicity $=$. White, $\mathrm{SES}=$ Professional/executive, $\mathrm{BMI}=25$, Smoking status $=$ Non-smoker, Alcohol use $=8$ units per 
medRxiv preprint doi: https://doi.org/10.1101/2022.02.24.22271384; this version posted February 25, 2022. The copyright holder for this preprint (which was not certified by peer review) is the author/funder, who has granted medRxiv a license to display the preprint in

All rights reserved. No reuse allowed without permission.

week, Physical activity $=13$ hours weekly of moderate to vigorous, Total cholesterol $=5.2 \mathrm{mmol} / \mathrm{L}$, Triglycerides= $1 \mathrm{mmol} / \mathrm{L}, \mathrm{HbA} 1 \mathrm{c}=5.6 \%$, Systolic blood pressure $=124 \mathrm{mmHg}$, Antihypertensive medication= Not using, Glucose lowering medication $=$ Not using)

\section{Estimation of heart rate adjusted HRV indices}

Calculated interbeat interval (IBI) or heart period in milliseconds

$$
I B I=\frac{60,000 m s}{r H R}
$$

Adjusted SDNN indices

$$
c S D N N=100 * \frac{S D N N}{I B I}
$$

Adjusted RMSSD indices

$$
c R M S S D=100 * \frac{R M S S D}{I B I}
$$

Adjusted HF indices

$$
c H F=10000 * \frac{H F}{I B I^{2}}
$$

Adjusted LF indices

$$
c L F=10000 * \frac{L F}{I B I^{2}}
$$

\section{Model specification by R-code using the nlme package}

\section{Step 1 analysis: Individual specific HRV levels and change}

\section{Non-adjusted HRV}

$\operatorname{lme}(\log (\mathrm{HRV}) \sim$ age, random $=$ age $\mid$ ID, method = "REML", na.action $=$ na.omit, data $=$ Whitehall II $)$

\section{Adjusted HRV}

$\operatorname{lme}(\log (\mathrm{cHRV}) \sim$ age, random $=$ age $\mid$ ID, method $=$ "REML", na.action $=$ na.omit, data $=$ Whitehall II $)$

\section{Resting heart rate}

lme $($ rHR $\sim$ age, random $=$ age $\mid$ ID, method $=$ "REML", na.action = na.omit, data $=$ Whitehall II $)$

\section{Step 2 analysis: Association between HRV level and change and the development of PWV}

\section{Non-adjusted HRV}

Model 1: $1 \mathrm{me}(\mathrm{PWV} \sim$ age * HRV intercept + age * HRV slope + sex + ethnicity, random = 1 | ID, method = "REML", na.action $=$ na.omit, data $=$ Whitehall II) 
medRxiv preprint doi: https://doi.org/10.1101/2022.02.24.22271384; this version posted February 25, 2022. The copyright holder for this preprint (which was not certified by peer review) is the author/funder, who has granted medRxiv a license to display the preprint in perpetuity.

All rights reserved. No reuse allowed without permission.

Model 2: Ime(PWV age * HRV intercept + age * HRV slope + sex + ethnicity + socio-economic status + BMI + smoking status + alcohol use + physical activity + total cholesterol + triglycerides + Hbalc + systolic blood pressure + anti-hypertensive medication + antidiabetic medication, random $=1 \mid$ ID, method = "REML", na.action = na.omit, data $=$ Whitehall II)

\section{Adjusted HRV}

Model 1: 1me(PWV $\sim$ age * cHRV intercept + age * cHRV slope + sex + ethnicity, random $=1 \mid \mathrm{ID}$, method $=$ "REML", na.action = na.omit, data $=$ Whitehall II)

Model 2: lme(PWV $\sim$ age $*$ cHRV intercept + age $*$ cHRV slope + sex + ethnicity + socio-economic status + BMI + smoking status + alcohol use + physical activity + total cholesterol + triglycerides + Hbalc + systolic blood pressure + anti-hypertensive medication + antidiabetic medication, random $=1 \mid$ ID, method = "REML", na.action = na.omit, data = Whitehall II)

\section{Resting heart rate}

Model 1: $1 \mathrm{me}(\mathrm{PWV} \sim$ age * rHR intercept + age * rHR slope $+\mathrm{sex}+$ ethnicity, random $=1 \mid \mathrm{ID}$, method $=$ "REML" na.action $=$ na.omit data $=$ Whitehall II)

Model 2: lme $(\mathrm{PWV} \sim$ age $*$ rHR intercept + age $*$ rHR slope + sex + ethnicity + socio-economic status + BMI + smoking status + alcohol use + physical activity + total cholesterol + triglycerides + Hbalc + systolic blood pressure + anti-hypertensive medication + antidiabetic medication, random $=1 \mid$ ID, method $=$ "REML", na.action $=$ na.omit, data = Whitehall II) 